\title{
Expansionary Austerity and Reverse Causality: A Critique of the Conventional Approach
}

\author{
Christian Breuer ${ }^{1}$
}

\section{Working Paper No. 98}

June 2019

\begin{abstract}
In this paper we methodologically review and criticize a broad literature of empirical work on the effects of fiscal policy (the 'conventional approach'). Beyond previous critiques of this approach, we show that the cyclical adjustment strategy as used in this literature entails erroneous assumptions that necessarily produce flawed results in support of expansionary austerity. Specifically, the cyclically-adjusted primary balance (CAPB) strategy this literature employs fails to correct for cyclical effects in the expenditureGDP-ratio, so that the estimates of the results of expansionary fiscal consolidation are affected by reverse causality, i.e. increasing GDP causally decreases expenditure-GDPratios, rather than vice versa. We provide suggestions on how to fix this incomplete cyclical adjustment problem with a new approach. After replicating two famous articles
\end{abstract}

\footnotetext{
${ }^{1}$ Chemnitz University of Technology christian.breuer@wirtschaft.tu-chemnitz.de
}

We thank Olivier Blanchard for helpful comments on a previous version of this paper, and Pablo Hernández de Coz and Enrique Moral-Benito for kindly sharing their data, which is based on the data used in Alesina and Ardagna (2010). 
of the conventional literature and controlling for this bias, the expansionary effects of fiscal adjustments disappear or turn into their opposites.

JEL Codes: E60, E62, E65

Keywords: Austerity; Fiscal adjustment; Conventional approach; Blanchard method; Cyclical adjustment; Reverse causality 


\section{Introduction}

One of the lively debates in today's macroeconomic research is the question of the effects of fiscal policy. In the European fiscal crisis, this debate has gained political importance since policy-makers have been searching for an efficient way to reduce government debt. The idea of an "expansionary fiscal contraction" seemed to be a solution for the challenges of the time. While most of the research on fiscal policy suggests that fiscal consolidations negatively affect economic growth, one stream of literature finds that fiscal adjustments may have expansionary effects ('expansionary austerity hypothesis'). This stream of literature analyses economic growth during episodes when the cyclicallyadjusted primary balance (CAPB) increases (data-based or conventional approach).

Using this approach and a cyclical-adjustment strategy motivated by Blanchard (1990), Alesina and Perotti (1995) provided the first evidence in support of expansionary austerity in a large panel of OECD countries. ${ }^{2}$ Subsequent research based on the conventional approach regularly applied the method as developed in Alesina and Perotti (1995) to compute the CAPB. ${ }^{3}$ Most of these studies find that fiscal adjustments at the spending side are associated with economic growth (for example Alesina and Ardagna, 1998, 2010, 2013). Until today, the conventional approach is associated with the cyclical adjustment method proposed by Alesina and Perotti (1995), as well as the expansionary austerity hypothesis. ${ }^{4}$

In contrast to this view, Guajardo et al. (2014) propose another fiscal indicator, the historical or narrative approach, which is based on historical records and a narrative analysis of fiscal policy documents. They do not find evidence in support of expansionary

\footnotetext{
${ }^{2}$ Referring to Blanchard (1990), the authors use the term "Blanchard method" for their strategy to compute the CAPB or the "Blanchard Fiscal Indicator" (BFI). Since our critique of this approach does not address the suggestions made in Blanchard (1990), we do not use this term for the method of Alesina and Perotti (1995).

${ }^{3}$ The literature based on this approach consists of, for example, Alesina and Perotti (1995 and 1997), Alesina and Ardagna (1998, 2010 and 2013), as well as Ardagna (2004 and 2009). This work belongs to an influential stream of literature on the effects of fiscal policy and has been cited extensively. According to Google Scholar, Alesina und Perotti (1995) have been cited 1,484 times, and Alesina and Ardagna (2010) 1,388 times (in April, 2019). Even more influential has been the effect on policy consulting and policymakers during the European fiscal crisis (see for example Blyth, 2013 and Stiglitz, 2016).

${ }^{4}$ Refer to Guajardo et al. (2014).
} 
austerity. However, recent research based on the narrative approach suggests that the evidence based on the narrative approach is in line with the findings of the conventional approach (see Alesina, Favero and Giavazzi, 2018 and 2019). The evidence presented in this more recent literature again finds that fiscal consolidations on the spending side are positively associated with GDP growth in the short run. This suggests that the methods and findings of the conventional approach are not regarded as outdated and that the debate between the 'conventional' and the 'narrative approach' remains inconclusive. Since the literature on expansionary austerity is now back in the media and policy debate, it might be helpful to better understand the findings and pitfalls of the previous literature on expansionary austerity.

In this paper we methodologically review and technically criticize the conventional approach in the tradition of Alesina and Perotti (1995). Parts of this literature have already been criticized before. However, previous critiques failed to bring out one important reason why the conventional approach based on the CAPB and the method of Alesina and Perotti (1995) is biased towards expansionary effects, namely that the cyclical adjustment strategy as used in this literature entails erroneous assumptions that necessarily produce flawed results in support of expansionary austerity on the spending side. More specifically, the CAPB as used in this literature fails to correct for cyclical effects in the expenditure-GDP-ratio, so that the estimates of the results of expansionary fiscal consolidation are affected by reverse causality, i.e. increasing GDP causally decreases expenditure-GDP-ratios, rather than the other way around.

We give suggestions on how to fix this mistake with a new and corrected approach to compute the CAPB based on the ideas put forward in Blanchard (1990). We show how this simple correction influences the results (method B). Replicating two particularly famous contributions based on the conventional approach and the approach of Alesina and Perotti with the corrected cyclical adjustment method, the expansionary effects of fiscal adjustments disappear or reverse.

The cyclical adjustment problem in the method proposed by Alesina and Perotti (1995) and applied in Alesina and Ardagna (1998, 2010, and 2013) is particularly severe in the 
case of government expenditures. This explains why the estimated fiscal multipliers in the literature based on the conventional approach and the method as proposed by Alesina and Perotti (1995) are biased towards expansionary effects, particularly in the case of expenditure cuts.

The remainder of this paper is structured as follows. Section 2 summarizes the literature on expansionary austerity and discusses the relevance of previous critiques. Section 3 illustrates that the strategy pioneered by Alesina and Perotti (1995) is in conflict with assumptions made in the literature on cyclical adjustment. Different from the literature on cyclical adjustment, Alesina and Perotti (1995) implicitly assume unit-elastic government expenditures with respect to GDP, while it is common to assume inelastic government expenditure (other than transfers). To fix the incomplete cyclical-adjustment problem, we propose an augmented approach to compute the CAPB based on the suggestions of Blanchard (1990), which is in line with standard assumptions of fiscal cyclicality.

Our paper then tests the hypotheses outlined in section 3 based on the dataset used in Alesina and Ardagna (2010). The results of Alesina and Ardagna (2010) are compared with those based on the CAPB (as computed with standard assumptions by the OECD) and the corrected method as proposed in section $3 .^{5}$

The empirical section 4 provides evidence for the hypothesis that the fiscal indicator as used in Alesina and Ardagna (2010) entails a pro-cyclical pattern and is positively correlated with the output gap, while the same is not true for the CAPB of the OECD or the corrected version of the CAPB as proposed here. This pattern appears to be particularly pronounced for the expenditure-GDP-ratio (if calculated with the wrong method as in Alesina and Ardagna (2010)) and suggests that the cyclical adjustment problem as discussed in section 3 is quantitatively important. We replicate Alesina and

\footnotetext{
${ }^{5}$ We use the same data and definitions as Alesina and Ardagna (2010), precisely the OECD Economic Outlook, No. 84, as applied in Alesina and Ardagna (2010). As a standard cyclical adjustment strategy we obtain cyclically-adjusted data from the same source, based on the method proposed in Girouard and André (2005), as well as a newly developed CAPB based on the suggestions of Blanchard (1990) that corrects the incomplete cyclical adjustment problem of the Alesina and Ardagna approach.
} 
Ardagna (2010) and compare the estimated effects of changes in fiscal policy (based on the CAPB used in Alesina and Ardagna, the CAPB of the OECD, and the corrected method). In line with the hypotheses formulated in section 3, it is shown that only the results based on the approach used in Alesina and Ardagna (2010) provide evidence for expansionary effects of fiscal contractions in the case of expenditure cuts, while this effect is contractionary after using standard assumptions to correct for cyclical effects. The paper shows that there is a qualitative difference in the estimated fiscal multiplier if standard methods are used to compute the CAPB, rather than the method proposed by Alesina and Perotti (1995) and applied by Alesina and Ardagna. This indicates that the positive relationship between fiscal retrenchment and growth in the literature of the conventional approach between 1995 and 2013 reflects reverse causality, rather than findings in support of the expansionary austerity hypothesis. But this is the opposite of what this literature claims. Section 5 concludes.

\section{Literature}

Macroeconomic textbooks in the Keynesian tradition suggest that fiscal expansions increase and fiscal consolidations contract aggregate demand. A reduction of government deficit levels would thus decrease economic growth in the short run. On the other hand a substantial amount of empirical research on the macroeconomic effects of fiscal consolidations finds that fiscal adjustments may have expansionary effects ('expansionary austerity hypothesis'). This view was first expressed by Giavazzi and Pagano (1990) who discussed the expansionary effects of cases of fiscal adjustments in Ireland and Denmark during the 1980s. Alesina and Perotti (1995) found evidence for the expansionary austerity hypothesis in a large panel of OECD countries. Subsequently a number of papers built on the approach used in Alesina and Perotti (1995) to investigate the effects of fiscal policy. ${ }^{6}$ According to this stream of literature, fiscal consolidations are likely to be expansionary if the adjustment mainly takes place on the expenditure side,

\footnotetext{
${ }^{6}$ See for instance Alesina and Perotti (1997), Alesina and Ardagna (1998, 2010, and 2013), and Ardagna (2004 and 2009).
} 
while tax increases are more likely to be contractionary (Alesina and Ardagna, 1998, 2010, and 2013).

To measure discretionary changes in fiscal policy, Alesina and Perotti (1995) investigate changes in the CAPB and apply a newly developed cyclical adjustment strategy. Critiques of this approach are not new. In a comment on Alesina and Perotti (1995), Kollintzas (1995) suggests that the cyclical adjustment strategy used in Alesina and Perotti (1995) might not capture the cyclical effects of the government budget balance so that the resulting change in the CAPB might not be an appropriate measure of a discretionary change in fiscal policy. Giavazzi (1995) suggests that the results in Alesina and Perotti (1995) are influenced by accompanying monetary policies, in form of exchange rate devaluations, for example in the case of Ireland 1987.

At the beginning of the European fiscal crisis, there was a renewed interest in the effects of fiscal consolidations and their potentially expansionary effects. Against this background, Alesina and Ardagna $(2010,2013)$ provided new evidence on expansionary effects of fiscal consolidations based on the conventional approach in a panel of OECD countries. These studies have frequently been debated in the recent literature as well as among policymakers. ${ }^{7}$ Contrary to the conventional approach, Leigh et al. (2010) and Guajardo et al. (2014) analyzed historical records of fiscal adjustments and contrasted the conventional approach with the historical or narrative approach. Their results did not confirm the expansionary austerity view. ${ }^{8}$

Guajardo et al. (2014) showed that the fiscal indicator used in Alesina and Ardagna (2010) is correlated with GDP forecast revisions. The authors state that estimates based on the conventional approach appear to be biased towards overestimating expansionary effects, since the conventional approach entails one-off operations in the budget balance.

\footnotetext{
${ }^{7}$ Refer to Callinicos (2012), Blyth (2013), Foresti and Marani (2014), and Stiglitz (2016) for a comprehensive discussion and critique of expansionary fiscal consolidations and their relevance in the European fiscal crisis.

${ }^{8}$ The narrative approach today has recently been applied by a number of authors, as for instance in Alesina et al. (2015, 2018, and 2019). In this paper we focus on the incomplete cyclical adjustment problem in the conventional approach and do not discuss the advantages and disadvantages of the narrative approach in more detail.
} 
They also argue that the cyclical adjustment strategy of Alesina and Ardagna (2010) neglects the effects of budgetary effects of changes in asset prices. Moreover, Jayadev and Konczal (2010) as well as Jordà and Taylor (2016) illustrate that the successful cases of fiscal adjustments in Alesina and Ardagna (2010) are in most instances associated with an economic upswing, an analysis that questions the exogeneity of the fiscal indicator used in Alesina and Ardagna (2010). In this line, de Cos and Moral-Benito (2013) show that fiscal adjustment episodes as identified by Alesina and Ardagna (2010) are not exogenous to economic growth and treat fiscal consolidations as weakly exogenous or predetermined, pointing to potential feedback effects or reverse causality.

To account for potential endogeneity in the study of Alesina and Ardagna (2010), Breuer (2013), Holden and Midthjell (2013), and Yang et al. (2015) apply alternative measures of discretionary change and illustrate that the positive effects of fiscal adjustments disappear after applying alternative adjustment of strategies of budgetary data for cyclical effects, rather than employing the method used in Alesina and Ardagna (2010). Since the method they used has also been criticised for the (non-) recognition of the effects of fluctuations in asset prices on the budget balance (Guajardo et al., 2014), Yang et al. (2015) developed an indicator of fiscal impulses which controls for asset price fluctuations. They discovered that the results are more in line with the narrative approach when the changes in the fiscal stance is measured with this alternative strategy. Holden and Midthjell (2013) discussed potential reverse causality in the study of Alesina and Ardagna (2010) and show that reductions in government spending are not more likely to be successful in terms of reducing government debt, compared to tax increases, if the CAPB is estimated with a modified strategy, rather than the one used by Alesina and Ardagna.

However, Holden and Midthjell (2013) as well as Yang et al. (2015) apply newly developed strategies to adjust for cyclical effects rather than applying standard methods and they do not show whether their assumptions are more in line with the literature compared to the assumptions made in Alesina and Perotti (1995) and in Alesina and Ardagna (1998, 2010, and 2013). Holden and Midthjell (2013) focus on the question of whether fiscal policies are effective in reducing debt, rather than examining the effect of 
the cyclical adjustment strategy on the estimated effect on GDP. No previous study has discussed why the method as used in the literature following Alesina and Perotti (1995) is in conflict with standard assumptions on automatic stabilizers and how fixing this conflict influences the estimated fiscal multiplier in conventional analyses of fiscal policy.

\section{Cyclical adjustment and reverse causality}

\subsection{Cyclical adjustment and the data-based approach}

To analyze the effects of changes in fiscal policy on GDP, the conventional (data-based) approach applies regressions of GDP growth rates $\Delta y_{t}$ in year $t$ on changes in the cyclically-adjusted primary budget balances (as a ratio of GDP) $\Delta c a p b_{t}$ :

$$
\Delta y_{t}=\alpha+\beta \Delta c a p b_{t}+\varepsilon_{t}
$$

The idea of this approach is straightforward: coefficient $\beta$ captures the effect of a change in fiscal policy (measured as a percentage point of GDP) on GDP growth rates, i.e. the fiscal multiplier. This approach can only provide unbiased estimates of the fiscal multiplier if the fiscal indicator is not endogenous to GDP (no reverse causality). Because the budget balance is influenced by a number of factors that might be correlated with the economic cycle, however, the question of reverse causation has frequently been discussed. Perotti (2013) highlights two potential pitfalls of empirical papers on the effects of fiscal policy using the conventional approach, the "countercyclical response problem," and the "imperfect cyclical adjustment problem."

Since the cyclical adjustment strategy aims at controlling for automatic feedback effects of GDP on the budget balance, the most obvious reason why the budget balance responds to GDP seems to be controlled for, however, an "incomplete cyclical adjustment problem" arises when the cyclical adjustment strategy does not appropriately account for cyclical effects in the budget balance, e.g., because it does not take into account changes in asset prices. In this context, a number of articles discuss the influence of asset prices 
on the budget balance. ${ }^{9}$ According to Perotti (2013) another problem might arise through discretionary fiscal policy. For example, it is possible that systematic counter-cyclical policy responses might contribute to the positive relationship between the budget balance and economic growth ("counter-cyclical response problem"). Accordingly, the estimated coefficient $\beta$ is an unbiased assessment of the fiscal multiplier only under the assumption of no "imperfect cyclical adjustment problem" and no "counter-cyclical response problem." In the following, we focus on the incomplete cyclical-adjustment problem in the literature using the conventional approach and the method to adjust for cyclical effects in the tradition of Alesina and Perotti (1995). ${ }^{10}$

\subsection{The 'conventional approach' of Alesina and Perotti (1995)}

According to the literature on the cyclical adjustment of government budget data (e.g. Fedelino et al., 2009), the CAPB in year $t$ consists of revenues $R_{t}$ net of government expenditure $G_{t}$, both adjusted with their sensitivity to GDP $\varepsilon_{R}$ and $\varepsilon_{G}$ (with $Y_{t}$ being GDP and $Y_{t}^{P}$ representing potential GDP) ${ }^{11}$ :

$$
C A P B_{t}=R_{t}\left(\frac{Y_{t}^{P}}{Y_{t}}\right)^{\varepsilon_{R}}-G\left(\frac{Y_{t}^{P}}{Y_{t}}\right)^{\varepsilon_{G}}
$$

The literature proposes the following simplifying assumptions (Fedelino et al., 2009): unit-elastic revenues (responding to the tax base with an elasticity of 1 ), $\varepsilon_{R}=1$, and inelastic government expenditure ( $\varepsilon_{G}=0$ ). If so, equation (2) can be simplified to

$$
C A P B_{t}=R_{t}\left(\frac{Y_{t}^{P}}{Y_{t}}\right)-G_{t}
$$

Under the assumptions made, it appears to be reasonable to adjust revenues but not expenditure. Only few expenditure items (unemployment benefits) are affected by the economic cycle. Following this idea Alesina and Perotti (1995) assume that social

\footnotetext{
${ }^{9}$ See Morris and Schuknecht (2007) and Yang et al. (2015) on how asset price fluctuations might influence the budget balance and the estimated fiscal multiplier in the conventional approach.

${ }^{10}$ See appendix A for technical details.

${ }^{11}$ Note that the CAPB in this illustration is not calculated as a ratio of GDP.
} 
transfers to households (as an exception of expenditures), as well as revenues (and only transfers and revenues) respond to cyclical effects and apply the cyclical adjustment procedure to taxes and transfers, whereas expenditures other than transfers remain unadjusted. According to Alesina and Perotti (1995) $)^{12}$, the $\triangle \mathrm{CAPB}$ is ${ }^{13}$

$$
\Delta C A P B_{t}=\Delta R_{t}-\alpha_{R} \Delta U R_{t}-\left(\Delta \operatorname{Tr}_{t}-\alpha_{T r} \Delta U R_{t}\right)-\Delta G_{t}
$$

Rather than computing estimates of potential GDP and output elasticities, it is necessary to compute estimates of the elasticities of transfers and tax revenues to unemployment $U R_{t}\left(\alpha_{R}\right.$ and $\left.\alpha_{T r}\right) \cdot{ }^{14}$

While this definition of the CAPB is theoretically correct, the application in the literature following Alesina and Perotti (1995) is in conflict with standard methods to compute cyclically-adjusted budget balances, as for example the OECD approach (Girouard, André, 2005, or as described in Fedelino et al., 2009). The mistake of Alesina and Perotti (1995) is that they do not adjust levels of revenue and expenditure, but revenue and expenditure as a ratio of GDP. To use the variables in data-based analyses of fiscal policy it is helpful to scale the CAPB as a ratio of GDP (as it is done in the literature and in Alesina and Perotti, 1995). Using the CAPB-to-GDP ratio and assuming unit-elastic revenues $\varepsilon_{R}=1$ as well as inelastic government expenditure $\varepsilon_{G}=0$ the $\operatorname{capb}$ (CAPB as a ratio of GDP) yields

$$
c a p b_{t}=\frac{R_{t}}{Y_{t}}-\frac{G_{t}}{Y_{t}}\left(1+\operatorname{gap}_{t}\right)
$$

The result is different from the CAPB without scaling in equation (3). Using revenues and expenditures as a ratio of GDP, standard assumptions would suggest adjusting expenditure (as a ratio of GDP), rather than revenue (as a ratio of GDP). ${ }^{15}$

\section{3. Incomplete cyclical adjustment and reverse causality}

\footnotetext{
${ }^{12}$ The idea to use the unemployment rate as a natural indicator of the economic cycle rather than the estimated output gap is basically the suggestion made in Blanchard (1990).

${ }^{13}$ The definition remains relatively similar to the following papers, as for example in Alesina and Ardagna (1998, 2010, 2013).

${ }^{14}$ See Appendix A for a more technical discussion of the approach of Alesina and Perotti (1995).

${ }^{15}$ In line with this Alesina and Perotti (1995) note that using the primary deficit as a share of GDP "is not a bad approximation as long as expenditures and revenues are close to being unit elastic to GDP." However, according to the literature (for example Fedelino et al, 2009), this is a bad approximation in the case of expenditures.
} 
Using equations (5) and (1) to measure the effect of fiscal policy on growth (if $\varepsilon_{R}=1$ and $\varepsilon_{G}=0$ ) and leaving the expenditure-GDP-ratio unadjusted gives

$$
\Delta Y_{t}=\alpha+\beta\left(\Delta\left(\frac{R_{t}}{Y_{t}}\right)-\Delta\left(\frac{G_{t}}{Y_{t}}\left(1+\operatorname{gap}_{t}\right)\right)\right)+u_{t}
$$

Following Alesina and Perotti (1995) and correcting only taxes and transfers (as a ratio of GDP), the estimated CAPB (as a ratio of GDP) includes cyclical effects (in the denominator) and consists of (adjusted) revenues as a ratio of GDP; $\left(C A R_{t}\right)$, net of (adjusted) transfers as a ratio of GDP ( $\left.C A T r_{t}\right)$, and the ratio of (unadjusted) government expenditure (other than transfers) to GDP $\left(E_{t} / Y_{t}\right)$ :

$$
\Delta Y_{t}=\alpha+\beta \Delta\left(C_{t}-\operatorname{CATr}_{t}-\frac{E_{t}}{Y_{t}}\right)+u_{t}
$$

It turns out that, by approximation, the expenditure-to-GDP ratio behaves inversely proportional to the output gap. It is obvious that the ratio of government expenditure other than transfers can be influenced by two separate factors, discretionary policy changes that influence the structural expenditure ratio $\left(\Delta e_{t}\right)$ and cyclical effects $\left(\Delta G a p_{t}\right)$. Even without policy changes $\left(\Delta C A R_{t}=0, \Delta C A \operatorname{Tr}_{t}=0\right.$, and $\left.\Delta e_{t}=0\right)$, and under the simplifying assumption that output growth is a sum of (constant) trend output growth $c$ and changes in the output gap ( $\left.\Delta Y_{t}=c+\Delta G_{a p}\right)$, equation (7) becomes:

$$
c+\Delta \operatorname{Gap}_{t}=\alpha+\beta e_{t} \Delta \operatorname{Gap}_{t}+u_{t}
$$

An increase in the output gap ( $\Delta G a p$ ) influences both sides of equation (8). The conventional method as proposed by Alesina and Perotti (1995) however might interpret an economic upswing (increase in the output gap) as reduction in government spending. ${ }^{16}$

\subsection{A simple correction of the 'Conventional Approach'}

\footnotetext{
${ }^{16}$ Appendix A provides a more technical analysis of the method of Alesina and Perotti (1995) as applied in Alesina and Ardagna (1998, 2010, 2013).
} 
The simplest way of solving the reverse causality problem in the previous versions of the conventional approach as discussed above is to use expenditures as a ratio of potential or trend GDP, rather than as a ratio of GDP. ${ }^{17}$ Different from Alesina and Perotti (1995), we therefore use an alternative specification of the CAPB computed with a corrected 'Blanchard method', where all fiscal items that are supposed to be inelastic (or close to being inelastic, such as government expenditure and revenue other than taxes and social security contributions) are scaled by trend GDP, while the items that are supposed to be unit elastic (or close to unit elastic, such as taxes and social contributions), are treated as proposed in Alesina and Perotti (1995). With this single exception, our new version of the Blanchard Fiscal Indicator is computed exactly the same way as proposed in Alesina and Perotti (1995) and in Alesina and Ardagna (2010). ${ }^{18}$ Note that the reverse causality problem as highlighted in equation (7) and (8) disappears after correcting for cyclical effects in the denominator of the expenditure ratio. ${ }^{19}$ After controlling for the bias resulting from the incomplete cyclical adjustment problem as shown in section 2.4, we replicate the results shown in the literature based on the conventional approach with our new indicator to see whether there is a systematic influence of the cyclical adjustment strategy and the estimated fiscal multiplier.

\subsection{Hypotheses}

How would the different assumptions on the elasticities $\varepsilon_{R}$ and $\varepsilon_{G}$ in equation (2) influence estimates of parameter $\beta$ in conventional analyses of fiscal policy? Ignoring other pitfalls (countercyclical response problem, one-offs, and changes in asset prices), regressions of equation (6) can provide unbiased estimates of parameter $\beta$ only if the elasticities $\varepsilon_{R}$ and $\varepsilon_{G}$ are estimated correctly. However, if the method does not correctly adjust for cyclical effects, this would systematically affect the estimated multiplier, as shown in equation (8). Table 1 summarizes how different assumptions on $\varepsilon_{R}$ and $\varepsilon_{G}$

\footnotetext{
${ }^{17}$ I thank Olivier Blanchard for suggesting this in a comment on a previous version of the paper.

${ }^{18}$ See Appendix A for more details.

${ }^{19}$ Of course other potential issues of endogeneity, such as the countercyclical policy-response problem, are not tackled with this strategy.
} 
would affect the estimated fiscal multiplier in the presence of an imperfect cyclical adjustment problem.

Following the assumptions that $\varepsilon_{R}=1$ and $\varepsilon_{G}=0$, the consequence for the estimated fiscal multipliers is particularly pronounced in the case of expenditures. There is no systematic influence of incomplete cyclical adjustment in the case of revenues, since revenues as a ratio of GDP remain unaffected by the GDP cycle, if $\varepsilon_{R}=1$. However, the estimated fiscal multiplier for government expenditures will be biased towards expansionary austerity if we use the approach of Alesina and Perotti (1995) and do not correct the expenditure-ratio for cyclical effects, since the unadjusted ratio of expenditures to GDP is inversely related to the output gap.

Using equations (5) and (8), we derive the following testable hypotheses:

1.) The CAPB in conventional analyses (as proposed in Alesina and Perotti, 1995, and applied in Alesina and Ardagna, 2010 and 2013) is correlated with changes in the output gap (equation 5), while other fiscal indicators based on standard assumptions are not (or less so).

2.) This correlation is particularly pronounced on the expenditure side (government expenditure as a ratio of GDP) and less pronounced in the case of changes in revenues (as a ratio of GDP).

3.) The resulting estimated fiscal multiplier is small (or even negative) if the CAPB (as proposed in Alesina and Perotti, 1995) is used as fiscal impulse, while the estimated fiscal multiplier calculated in line with standard assumptions (the CAPB as used in the OECD Economic Outlook based on Girouard and André, 2005, or our new 'Blanchard method' as proposed in section 3.4) will show more positive multipliers more in line with Keynesian theory (equation 8).

4.) Differences in the estimates of the fiscal multiplier between results based on the approach of Alesina and Perotti (1995) and other versions of the CAPB are particularly pronounced in the case of changes in expenditures and less pronounced for changes in revenues. 


\section{Empirical evidence}

This section tests the hypotheses as derived in the previous section and replicates the evidence found in Alesina and Ardagna (2010 and 2013) based on the CAPB. We show that the results of the conventional approach are sensitive depending on the cyclical adjustment strategy applied. We therefore distinguish between three cyclicallyadjustment methods (Alesina and Perotti (1995); the OECD method; and our corrected method). ${ }^{20}$

\subsection{Endogeneity of fiscal indicators}

Section 2 has shown that the method of Alesina and Perotti (1995) suffers from an imperfect cyclical adjustment problem. To test hypothesis (1), that the CAPB in Alesina and Ardagna (2010) entails a (positive) cyclical pattern, Figure 1 compares (a) changes in the $C A P B$ (estimated according to Alesina and Ardagna, 2010), and (b) according to the definitions of the OECD with changes in the output gap, since an imperfect cyclical adjustment problem results in a (more) pro-cyclical behavior of $\triangle C A P B$. Figures 1 a) and b) show that the fiscal indicators measured according to Alesina and Perotti (1995) and in Alesina and Ardagna (2010) depict a more cyclical pattern, compared to the CAPB of the OECD (hypothesis 1).

Hypothesis 2 suggests that this pro-cyclical pattern stems from the expenditure side, while the revenue side remains unbiased. Figures 1 ( $c$ and d) depict the cyclical behavior of cyclically-adjusted government revenues (as used in Alesina and Ardagna, 2010, and the OECD method), and Figures 1 (e and f) show the comparable behavior of expenditures. Consistent with hypothesis 2, the pro-cyclical pattern in the data of Alesina and Ardagna (2010) is not visible for revenues (1c), but is particularly pronounced in the case of expenditures.

\footnotetext{
${ }^{20}$ Note that the results for the method of Alesina and Perotti (1995) are perfect replications of Alesina and Ardagna (2010). The data used in this paper is from the same source used in Alesina and Ardagna (2010), obtained from the OECD Economic Outlook no. 84. The c.a. procedure of the OECD is described in Girouard and André (2005) and the corrected Blanchard method is specified as discussed in section 3.4.
} 
We quantitatively explore the cyclical pattern of the fiscal indicators $\Delta F_{i t}$ with two-way fixed-effects regressions of the following form ${ }^{21}$

$$
\Delta F_{i t}=\mu_{i}+\lambda_{t}+\gamma \Delta \operatorname{Gap}_{i t}+u_{i t}
$$

Here, $\mu_{i}$ and $\lambda_{t}$ represent country and time fixed effects. Table 2 shows the estimated coefficient $\gamma$, for regression (17) using different fiscal indicators $\Delta F_{i t}$. We distinguish between three indicators (primary balance, current revenues, as well as current expenditures) and four cyclical adjustment approaches (no adjustment, the CAPB according to Alesina and Ardagna, 2010, the OECD method, and the corrected method).

The results are in-line with the evidence shown in Figure 1. Without cyclical adjustment, there is a strong positive relationship between changes in the output gap and the CAPB, as a consequence of changes in the cyclical position. As predicted, the pro-cyclical behavior stems from the expenditure side, since the expenditure ratio is negatively related to GDP. This pattern appears to be less pronounced but persists if the Alesina and Ardagna (2010) measure is applied, pointing to the presence of an imperfect cyclical adjustment problem, while the CAPB of the OECD appears to be uncorrelated to changes in the economic cycle. Using the corrected method the results turn out to be slightly counter-cyclical.

Looking at government revenues, the unadjusted series are negatively correlated to the output gap, pointing to a short-run elasticity of $\varepsilon_{R}<0$. However, after applying any cyclical adjustment procedure, the cyclicality of revenues disappears.

As proposed by hypothesis 2, the indicators of government expenditures (as a ratio of GDP) are negatively associated with the economic cycle, which is strongly pronounced in the case of the unadjusted indicators. Adjusting the expenditure ratio with the method

\footnotetext{
${ }^{21}$ Guajardo et al. (2014) analyze fiscal cyclicality in a comparable framework to show that the CAPB (as used in Alesina and Ardagna) shows a cyclical pattern, while the narrative measure of fiscal activity does not. Different from Guajardo et al. (2014) I do not use narrative measures of fiscal policy as a reference, but use CAPB based on standard definitions, as provided by the OECD, and use the change in the output gap as cyclical indicator rather than GDP growth rate revisions. Note that using forecast revisions instead does not qualitatively change our results and forecast revisions are influenced by recent cyclical information.
} 
of Alesina and Perotti (1995), the counter-cyclical pattern remains at a slightly lower level, while the relationship disappears after applying the OECD measure and even reverses after applying the corrected method. ${ }^{22}$

Given these illustrations and positive tests of hypothesis (1) and (2), it appears to be reasonable that the cyclical adjustment problem in Alesina and Ardagna (2010) exists and is quantitatively important. We continue with tests of hypotheses (3) and (4).

\subsection{Replication analysis and sensitivity}

As discussed in the previous section, Alesina and Ardagna (2010) examine episodes of large changes in the fiscal stance, defined as years where the CAPB increases/decreases by more than 1.5 percentage points. The selected episodes by this definition, for three different methods (the method of Alesina and Ardagna, 2010, the CAPB of the OECD, as well as the corrected 'Blanchard method') are shown in appendix B. Tables 3 and 4 show the results of a replication of Alesina and Ardagna (2010) with the method of Alesina and Perotti (1995), the CAPB of the OECD, and the corrected method as a fiscal indicator. Similar to Alesina and Ardagna (2010) we analyze the effect of changes in the CAPB on GDP in episodes of large changes in the fiscal stance with regressions of the following form:

$$
\Delta y_{i t}=\alpha+\sum_{j=1}^{2} \alpha_{j} \Delta y_{i t-j}+\beta \Delta c a p b_{i t}+\gamma X+u_{i t}
$$

Equation (10) is basically an augmented version of regression (1), after including controls, with two lags of the endogenous variable and other controls $(X)$. Table 3 shows the results for the analysis of major episodes of fiscal expansions. While column (1) and (2) are perfect replications of the results in Alesina and Ardagna, column (3) and (4) show the same results, with the only difference that the CAPB is used as provided by the OECD (using the same data as Alesina and Ardagna, 2010, the OECD Economic outlook no. 84), rather than calculated with the method of Alesina and Perotti (1995).

\footnotetext{
22 The results are very much in line if we use GDP growth or GDP growth forecast revision as an alternative cyclical indicator rather than the output gap.
} 
Column (5) and (6) illustrate the same results based on the corrected method that fixes the reverse causality problem of the Alesina and Perotti (1995) approach, as suggested in section 3.4. While the CAPB of Alesina and Perotti (1995) selects 72 episodes, the number of episodes selected by the CAPB of the OECD and the corrected approach decreases substantially (65 and 64). While the positive (expansionary) effect of fiscal consolidations decreases after using the CAPB of the OECD, the effect is not statistically significant in all three regressions (column 1, 3, 5). Column (2), (4) and (6) distinguish between the effects of current expenditure, investment and revenue. The results based on the approach of Alesina and Perotti (1995) and presented in Alesina and Ardagna (2010) show a clear negative relationship between expenditure and growth in episodes of fiscal stimuli. This relationship has been widely interpreted as evidence for a negative multiplier in the case of expenditure cuts (Alesina and Ardagna, 2010). However, using the CAPB of the OECD, this result decreases substantially and loses statistical significance (column 4). In column 6 the coefficient for expenditures even goes in the opposite direction after applying the corrected specification, suggesting that the conventional approach, if correctly specified, does not produce results in support of non-Keynesian effects of changes in government expenditures.

Table 4 illustrates the results for fiscal adjustments. As in the case of fiscal stimuli (Table 3), the number of observations decreases (from 88 to 76 and 80 ) after using the CAPB of the OECD (or the corrected method). Similar to the evidence in Table 3, the effect of fiscal consolidation based on the method used in Alesina and Ardagna (2010) is positive in column 1, suggesting evidence for expansionary austerity. The results based on the CAPB of the OECD, however, shows that fiscal consolidations appear to be negatively associated with GDP growth, suggesting a more Keynesian effect. Nevertheless, again the effect is not statistically significant. Columns 2, 4 and 6 distinguish between the effects of expenditure- and revenue- based fiscal consolidations. It turns out that the effect of revenues increases slightly if the OECD method is applied, while the effect of expenditure cuts on GDP decreases and loses statistical significance if the cyclical adjustment is based on the OECD method. Again, the negative effect of expenditures disappears after applying the corrected version of the conventional approach (Table 4). The negative multiplier for results based on the method of Alesina and Perotti (1995) 
seems to be more pronounced in the case of expenditure cuts, compared to increases in revenues (hypothesis 4), representing the incomplete cyclical adjustment problem.

The evidence presented in Tables 3 and 4 is however based on a limited and quite arbitrary number of observations so that it might be interesting to additionally analyze and compare the evidence based on the full sample and not rely only on the selective evidence for cases of large changes in fiscal policy. Table 5 replicates and enhances another result of Alesina and Ardagna (2010), that fiscal consolidations are positively associated with GDP, if the sample is not restricted to large episodes of discretionary change. Like Alesina and Ardagna (2010), we estimate regressions of the following form:

$$
\Delta y_{i t}=\sum_{j=1}^{2} \alpha_{j} \Delta y_{i t-j}+\beta_{k} \Delta c a b_{i t-k}+\lambda_{i}+\mu_{t}+u_{t}
$$

Here, the sample is not restricted to large cases of fiscal stimuli and adjustments and includes country- and time fixed effects. Again, columns (1) and (2) present perfect replications of the results in Alesina and Ardagna (2010), while columns (3) and (4) show the results based on the CAPB of the OECD, and (5) and (6) based on the corrected method. Comparing columns (1) and (3), the statistically significant positive effect of fiscal consolidation on GDP (expansionary austerity) disappears after using the CAPB of the OECD (in line with hypothesis 3). Using the corrected approach, column (5) suggests that fiscal consolidations have negative rather than positive effects. Further, the negative multiplier for expenditures (column 2) decreases substantially if we apply the OECD measure rather than the approach of Alesina and Perotti (column 4). The estimated effect once again reverses in column (6), after using the corrected approach (consistent with hypothesis 4).

As another more general replication study we apply the method proposed by Leigh et al. (2010) and Alesina and Ardagna (2013):23

\footnotetext{
${ }^{23}$ Since Alesina and Ardagna (2010) did not compute dynamic responses of fiscal policy, this table is not a replication of Alesina and Ardagna (2010), but we see this exercise as a replication of Alesina and Ardagna (2013), since the sample and data is comparable to Alesina and Ardagna (2013), where dynamic responses of changes in fiscal policy based on the method of Alesina and Perotti (1995) are estimated in a very similar framework.
} 


$$
\Delta Y_{i t}=\sum_{j=1}^{2} \alpha_{j} \Delta y_{i t-j}+\sum_{k=0}^{2} \beta_{k} \Delta c a p b_{i t-k}^{F A}+\lambda_{i}+\mu_{t}+u_{t}
$$

Again, $\Delta y_{i t}$ represents real GDP growth in country $i$ at time $t$ and $\Delta c a b_{i t}^{F A}$ denotes the estimated change in the cyclically adjusted primary balance (as a percentage of GDP) in periods of large fiscal adjustments ( $\Delta c a p b_{i t-k}>1.5$ p.p. of GDP) and zero otherwise. ${ }^{24}$ Again, we distinguish between three strategies to adjust for cyclical effects, the method as proposed by Alesina and Perotti (1995); the OECD method, as proposed by Girouard and André (2005); and our new approach as proposed in section 3.4 of this paper. $\lambda_{i}$ and $\mu_{t}$ represent cross-section and time fixed effects, respectively.

Table 6 shows the results of this specification. Column (1) shows a statistically significant positive association between fiscal adjustments (as defined by Alesina and Ardagna) and GDP (expansionary austerity). This non-Keynesian effect changes its sign in column (3), after using the cyclic adjustment strategy of the OECD, however the result is not statistically significant at conventional levels. After applying the new approach (column 5), the negative relationship even turns out to be statistically significant. Furthermore, column (2) shows a strong non-Keynesian effect of expenditure cuts on GDP (based on the method used in Alesina and Ardagna (2013)), but this result reverses after using the OECD measure and even increases substantially after applying the corrected approach. This clearly supports hypothesis 3 and 4, meaning that the conventional results (based on the method proposed by Alesina and Perotti(1995), are biased towards expansionary austerity and that this bias is particularly pronounced for expenditure cuts.

Figure 2 depicts the dynamic effects of changes in fiscal policy based on the results of equation (12), where we distinguish between the estimated effect of large changes in the CAPB as calculated with the method proposed Alesina and Perotti (1995) and large changes in the CAPB as provided by the OECD. Similar to Alesina and Ardagna (2013),

\footnotetext{
${ }^{24}$ In an augmented specification we include changes in cyclically-adjusted current revenues and changes in cyclically-adjusted current primary spending in periods of large fiscal adjustments rather than changes in the CAPB during the same year. Alesina and Ardagna (2013) use a slightly different definition of "major cases" of fiscal adjustments; however, the pitfalls of their cyclical adjustment strategy (Alesina and Perotti, 1995) are similar so we consider this exercise as a replication and sensitivity test of Alesina and Ardagna (2013).
} 
we compute dynamic response functions, depicting the estimated response of GDP to a one-percentage point fiscal consolidation after a given period. According to the estimated regressions (Table 5), the dynamic response varies with the measure of fiscal policy.

A comparison of the results show that the estimated contractionary effect of fiscal adjustments based on the CAPB of the OECD is more pronounced compared to the results with the method proposed by Alesina and Perotti (1995). While the response of GDP to consolidation as estimated with the method of Alesina and Perotti (1995) shows some evidence for potential expansionary effects of fiscal adjustment, the results based on the CAPB of the OECD are relatively contractionary, and in line with hypothesis (3).

Figure 3 shows the estimated effect of a one percentage point increase in current revenues. In line with hypothesis 4 , the estimated effects of both approaches are relatively similar and contractionary, which is not surprising given that the elasticity of revenues is usually assumed to be approximately one, so that the revenue-to-GDP ratio does not necessarily need to be adjusted for automatic cyclical effects.

Figure 4 shows the same results for expenditure cuts. In line with hypothesis (4) the estimated effect of a one percentage point reduction in primary expenditures is very different depending on the method of how to adjust the data for cyclical effects. The approach of Alesina and Perotti finds expansionary effects of fiscal adjustments on the spending side. The (negative) impact multiplier is estimated to be -0.3 and turns out to be -0.4 after two years. ${ }^{25}$ If we apply the data provided by the OECD, the result is the opposite. The impact multiplier is 0.1 (positive), suggesting that a reduction in government spending has a negative impact on GDP. This observation is in line with hypothesis (4), where a negative correlation is expected between GDP growth and the expenditure-GDP ratio, if we do not appropriately correct the expenditure-GDP ratio for cyclical effects. ${ }^{26}$

\footnotetext{
25 These results are very much in line with the results in Alesina and Ardagna (2013), who found that a one percentage point reduction in government spending increases GDP by 0.15 percent in the same year and by 0.46 percent after two years. Note that these results presented in table 6 are not perfect replications of Alesina and Ardagna (2013), but comparable.

${ }^{26}$ Alesina and Ardagna (2010) state that their results are not affected by the method applied to adjust for cyclical effects, and that the results remain robust, even without controlling for cyclical effects. Indeed, the
} 
Along these lines, figures 5, 6, and 7 depict the response of GDP to a one percentage point fiscal consolidation and compare the response of GDP to fiscal adjustments as identified in Alesina and Ardagna (2010) with the response to adjustments as identified with the corrected approach as outlined in chapter 3.4. Similar to the evidence discussed in Figures 2, 3, and 4 and in line with hypotheses (3) and (4), the results support the view that Alesina and Ardagna (2010) underestimate the contractionary effects of expenditure based consolidations because of their erroneous strategy of adjusting the data for cyclical effects.

Since the conventional approach has been criticized for not controlling for one-off operations (Guajardo et al, 2014), as a test for robustness, all regressions are estimated using an alternative CAPB of the OECD, which excludes one-off operations, the so-called underlying balance. ${ }^{27}$ After using these indicators, the results turn out to be even more pronounced and statistically significant.

\section{Conclusion}

The reverse causality argument proposed in this article focuses on the incomplete cyclical adjustment problem in the approach of Alesina and Perotti (1995) to adjust for cyclical effects in budgetary data with the help of the so-called "Blanchard method" to compute the 'Blanchard Fiscal Indicator', which is relevant in a large number of subsequent studies based on the same approach, as for instance in Alesina and Ardagna (1998, 2010 and 2013), Ardagna (2002 and 2009), as well as Guajardo et al. (2014).

Our critique of the method proposed by Alesina and Perotti (1995) is that Alesina and Perotti (1995) implicitly assume unit-elastic government expenditure (other than transfers) with respect to GDP. Conversely, standard cyclical adjustment procedures

latter seems to be true. The estimated effects of fiscal consolidations based on the Alesina and Perotti (1995) approach are almost identical to those estimated with unadjusted data however both results would reflect reverse causality.

${ }^{27}$ Refer to Joumard et al. (2008) for a discussion on how one-off operations influence the budget balance and the definition of the underlying primary balance. 
assume inelastic expenditures other than transfers (Girouard and André, 2005). The theoretical discussion in this paper states that the resulting imperfect cyclical adjustment problem influences the estimated multiplier in conventional (data-based) analyses of fiscal policy so that the results are biased towards expansionary austerity in the case of expenditure cuts. It is shown that the CAPB as proposed by Alesina and Perotti (1995) does not effectively adjust for cyclical effects in the case of expenditures and that the results in Alesina and Ardagna (2010) are affected by reverse causality, i.e. increasing GDP causally decreases expenditure-GDP-ratios, if we follow the standard literature on cyclical adjustment.

We propose a corrected approach to compute the Blanchard (1990) Fiscal Indicator to address the incomplete cyclical adjustment problem of the literature using the conventional approach and the method of Alesina and Perotti (1995). Replicating the results presented in Alesina and Ardagna (2010), and comparing the results based on the (conventional) method proposed by Alesina and Perotti (1995) with the results based on alternative CAPB-based measures (cyclically-adjusted according to the method proposed by Girouard and André, 2005, as well as our corrected approach), it is shown that the expansionary effect of fiscal consolidations disappears after appropriately controlling for cyclical effects and assuming expenditure to be different from unit-elastic.

The reverse causality argument proposed in this paper might help systemize a number of controversies in the recent literature. For example, it explains why the evidence on expansionary austerity so often reflects cases where output operates above potential (Jayadev and Konczal, 2010; de Cos and Moral-Benito, 2013; Jordà and Taylor, 2015) and why previous research has discovered that fiscal consolidations in Alesina and Ardagna are endogenous to growth (e.g. Guajardo et al., 2014). It explains why the literature based on the approach of Alesina and Perotti (1995) suggests that cuts in government expenditure are associated with macroeconomic expansions, while increasing revenues (as a ratio of GDP) are contractionary. While the latter finding is in line with the theoretical literature, the finding of expansionary effects in the case of expenditure cuts has been frequently highlighted in the academic debate as well as among policy-makers, particularly during the European fiscal crisis. 
This study shows that the finding of expansionary austerity reflects reverse causation, i.e. cyclical fiscal retrenchments result as a consequence of an economic upswing, rather than an economic upswing resulting from a discretionary cut in government expenditures. The cyclical adjustment strategy proposed by Alesina and Perotti (1995) does not effectively control for this reverse-causality. Results based on the conventional approach and the cyclical adjustment strategy of Alesina and Perotti (1995) are biased towards overestimating expansionary effects of fiscal consolidations.

This article may also make a more general contribution. Some studies have been critical of the conventional analyses of fiscal policy in the recent past (Guajardo et al, 2014). Nevertheless, there is an urgent need to analyze budget data and to improve cyclical adjustment strategies to proxy discretionary changes in fiscal policy and to estimate cyclically-adjusted budget data, as for example in the context of the newly established fiscal rules in Europe.

In this article it is shown that it is not the conventional data-based approach in general, but one specific method of adjusting the budget balance for cyclical effects that leads to flaws in previous analyses based on the conventional approach. In line with Yang et al. (2015), this article shows that the conventional approach per se is applicable if the cyclical position of the budget is correctly taken into account. Of course, there are other issues, as for instance the counter-cyclical response problem, as highlighted by Perotti (2013), as well as the presence of one-off operations (Guajardo et al, 2014) that need to be tackled to further improve the conventional approach. ${ }^{28}$

The paper at hand is one step in this direction. It establishes a new method for computing a corrected version of the Blanchard (1990) Fiscal Indicator that is designed to solve the incomplete cyclical adjustment problem in the previous literature (see e.g. Alesina and Perotti, 1995; Alesina and Ardagna, 1998, 2010, 2013; Alesina and Ardagna, 2004,

\footnotetext{
${ }^{28}$ To address both the issue of incomplete cyclical adjustment as well as of one-off operations, I would suggest using underlying balances as an indicator of fiscal policy for future research based on the conventional approach or the new corrected method as proposed in this paper, excluding one-offs or (net) capital transfers.
} 
2009). The present fiscal crisis in Europe has shown that estimates of potential output (and structural deficits) are prone to extensive revisions, so that real-time estimates of structural balances are of limited use. In line with Blanchard (1990) it would thus be reasonable to establish an alternative fiscal indicator which is not prone to large revisions and arbitrary measurement issues. This paper contributes to this discussion by suggestions on how to improve the Blanchard Fiscal Indicator as well as the literature on fiscal policy based on the conventional approach. 


\section{References}

Alesina, A. and S. Ardagna (1998), "Tales of Fiscal Adjustment”, Economic Policy 13, 489-585.

Alesina, A. and S. Ardagna (2010), "Large Changes in Fiscal Policy: Taxes vs. Spending", in: Brown, J. R. (ed.), Tax Policy and the Economy 24, Chicago: University of Chicago Press, 35-68.

Alesina, A. and S. Ardagna (2013), “The Design of Fiscal Adjustments”, in: Brown, J. R. (ed.), Tax Policy and the Economy 27, Chicago: University of Chicago Press, 19-67.

Alesina, A. and R. Perotti (1995), "Fiscal Expansions and Adjustments in OECD Countries", Economic Policy 10, 205-248.

Alesina, A. and R. Perotti (1997), "Fiscal Adjustments in OECD Countries: Composition and Macroeconomic Effects", NBER Working Paper 5730.

Alesina, A., C. Favero, and F. Giavazzi (2015), "The Output Effect of Fiscal Consolidation Plans", Journal of International Economics, 96, 19-42.

Alesina, A., C. Favero, and F. Giavazzi (2018), "What Do We Know About the Effects of Austerity?", AEA Papers \& Proceedings, 2018, 524-530.

Alesina, A., C. Favero, and F. Giavazzi (2019), “Austerity - When It Works and When it Doesn't', Princeton University Press, 2019.

Ardagna, A. (2004), "Fiscal stabilizations: When do they work and why", European Economic Review, 48, 1047-1074.

Ardagna, A. (2009), "Financial markets' behavior around episodes of large changes in the fiscal stance", European Economic Review, 53, 37-55. 
Blanchard, O. (1990), "Suggestions for a new set of fiscal indicators", OECD Economics Department Working Paper No. 79.

Blyth, M. (2013), “Austerity: The History of a Dangerous Idea”, Oxford University Press.

Breuer, C. (2013), "On the Identification and Macroeconomic Effects of Discretionary Changes in Fiscal Policy", MPRA Papers, No 52056.

Callinicos, A. (2012), Cambridge Journal of Economics, 36, 65-77.

De Cos, P. H. and Moral-Benito, E. (2013), "Fiscal Consolidations and Economic Growth", Fiscal Studies, 34, 491-515.

De Cos, P. H. and Moral-Benito, E. (2016), "On the predictability of narrative fiscal adjustments", Economics Letters, 143, 69-72.

Fedelino, A., Ivanova, A., Horton, M. (2009), “Computing Cyclically Adjusted Balances and Automatic Stabilizers", International Monetary Fund, Technical Notes and Manuals, $09 / 05$.

Foresti, P, and U. Marani (2014), "Expansionary Fiscal Consolidations: Theoretical Underpinnings and Their Implications for the Eurozone", Contributions to Political Economy, 33, 19-33.

Giavazzi, F. and M. Pagano (1990), "Can Severe Fiscal Contractions be Expansionay? Tales of Two Small European Countries”, NBER Macroeconomics Annual, 1990.

Giavazzi, F. (1995), "Comment on Fiscal Expansions and Adjustments in OECD Countries", Economic Policy, 1995, 240-241.

Girouard, N and C. André (2005), "Measuring cyclically-adjusted budget balances for OECD countries", OECD Economics Department Working Paper 434. 
Guajardo, J., D. Leigh, and A. Pescatori (2014), "Expansionary Austerity? International Evidence", Journal of the European Economic Association, 12, 949-968.

Holden, S., Midthjell, N. L. (2013), „Successful Fiscal Adjustments - Does the Choice of Fiscal Instruments Matter?", CESifo Working paper Series 4456.

Jayadev, A. and M. Konczal (2010), "The Boom Not the Slump: The Right Time for Austerity", New York: Roosevelt Institute.

Jordà, Ò. and Taylor, A. (2015), "The Time for Austerity: Estimating the Average Treatment Effect of Fiscal Policy", Economic Journal, 2016, 126, 219-255.

Joumard, I., M. Minegishi, C. Andre, C. Nicq, and R. Price (2008), “Accounting for oneoff operations when assessing underlying fiscal positions", OECD Economics Department Working Papers, 642.

Kollintzas, T. (1995), "Comment on Fiscal Expansions and Adjustments in OECD Countries", Economic Policy, 1995, 241-243.

Leigh, D., P. Devries, C. Freedman, J. Guajardo, Laxton, D. and A. Pescatori (2010), "Will It Hurt? Macroeconomic Effects of Fiscal Policy Consolidation", in: IMF World Economic Outlook October 2010, 93-124.

Morris, R., and L. Schuknecht (2007), "Structural balances and revenue windfalls: the role of asset prices revisited", European Central Bank Working Paper, 737.

Perotti, R. (2013), “The “Austerity Myth": Gain Without Pain?”, NBER Chapters, in: Fiscal Policy after the Financial Crisis, NBER.

Stiglitz, J. (2016), “The Euro: How a common currency threatens the future of Europe”, New York: W. W. Norton \& Company. 
Yang, W., Fidrmuc, J., Ghosh, S. (2015), "Macroeconomic effects of fiscal adjustments: A tale of two approaches", Journal of International Money and Finance, 57, 31-60. 
Table 1: Consequences of imperfect cyclical adjustment under different assumptions on revenue- and spending elasticities

\begin{tabular}{lll}
\hline If & Relation to gap & Effect on the estimated multiplier \\
\hline$\varepsilon_{R}>1$ & $\mathrm{R} / \mathrm{Y}$ (positive) & Underestimation of the (negative) revenue multiplier \\
$\varepsilon_{R}<1$ & $\mathrm{R} / \mathrm{Y}$ (negative) & Overestimation of the (negative) revenue multiplier \\
$\varepsilon_{G}>1$ & $\mathrm{G} / \mathrm{Y}$ (positive) & Overestimation of the (positive) expenditure multiplier \\
$\varepsilon_{G}<1$ & $\mathrm{G} / \mathrm{Y}$ (negative) & Underestimation of the (positive) expenditure multiplier \\
\hline
\end{tabular}

Table 2: Fiscal policy and changes in the output gap

\begin{tabular}{|c|c|c|c|c|}
\hline \multicolumn{5}{|c|}{ Equation estimated: $\Delta F_{i t}=\mu_{i}+\lambda_{t}+\gamma \Delta G a p_{i t}+\varepsilon_{i t}$} \\
\hline Measure of $\Delta F$ & $\gamma$ & s.e. & R-squared & Obs \\
\hline$\Delta \mathrm{PB}$ & $0.350 * * *$ & 0.061 & 0.298 & 669 \\
\hline$\triangle \mathrm{CAPB}$ (Alesina and Ardagna) & $0.188 * * *$ & 0.059 & 0.228 & 668 \\
\hline$\triangle \mathrm{CAPB}(\mathrm{OECD})$ & 0.019 & 0.052 & 0.160 & 653 \\
\hline$\triangle \mathrm{CAPB}$ (new approach) & $-0.116^{* *}$ & 0.055 & 0.168 & 668 \\
\hline Current revenues & $\beta$ & s.e. & R-squared & Obs \\
\hline$\Delta \mathrm{R}$ & $-0.107 *$ & 0.060 & 0.179 & 669 \\
\hline$\Delta \mathrm{CAR}$ ( Alesina and Ardagna) & -0.063 & 0.046 & 0.122 & 668 \\
\hline$\triangle \mathrm{CAR}(\mathrm{OECD})$ & -0.006 & 0.055 & 0.168 & 653 \\
\hline$\triangle \mathrm{CAR}$ (new approach) & -0.031 & 0.047 & 0.120 & 668 \\
\hline Current expenditures & $\beta$ & s.e. & R-squared & Obs \\
\hline$\Delta \mathrm{E}$ & $-0.409 * * *$ & 0.062 & 0.540 & 669 \\
\hline$\triangle \mathrm{CAE}$ ( Alesina and Ardagna) & $-0.222 * * *$ & 0.047 & 0.331 & 668 \\
\hline$\triangle \mathrm{CAE}(\mathrm{OECD})$ & 0.007 & 0.042 & 0.255 & 668 \\
\hline$\Delta \mathrm{CAE}$ (new approach) & $0.092 * *$ & 0.038 & 0.217 & 668 \\
\hline
\end{tabular}

Notes: The table reports point estimates and heteroscedasticity-robust standard errors. All specifications contain full set of country and time fixed effects (not reported in the table).

$* * *$ Significant at $1 \%, * *$ significant at $5 \%, *$ significant at $10 \%$. 
Table 3: Fiscal Stimulus and Growth

\begin{tabular}{|c|c|c|c|c|c|c|}
\hline \multicolumn{7}{|c|}{ Equation estimated: $\Delta Y_{i t}=\alpha_{1} \Delta Y_{i t-1}+\alpha_{2} \Delta Y_{i t-2}+\beta X+\gamma \Delta F S_{i t}+\varepsilon_{i t}$} \\
\hline \multirow[b]{2}{*}{ GDP growth (t-1) } & \multicolumn{2}{|c|}{$\begin{array}{cc}(1) & (2) \\
\text { Replication of Alesina } \\
\text { and Ardagna }(2010)\end{array}$} & \multicolumn{2}{|c|}{$\begin{array}{l}\text { (3) } \\
\text { Replication of Alesina } \\
\text { and Ardagna (2010) } \\
\text { using the CAPB of the } \\
\text { OECD }\end{array}$} & \multicolumn{2}{|c|}{$\begin{array}{c}\text { (5) } \\
\text { Replication of Alesina } \\
\text { and Ardagna (2010) } \\
\text { using our corrected } \\
\text { CAPB }\end{array}$} \\
\hline & $\begin{array}{c}0.468 * * * \\
(0.147)\end{array}$ & $\begin{array}{c}0.484 * * * \\
(0.133)\end{array}$ & $\begin{array}{c}0.528 * * * \\
(0.165)\end{array}$ & $\begin{array}{c}0.542 * * * \\
(0.164)\end{array}$ & $\begin{array}{c}0.252 \\
(0.185)\end{array}$ & $\begin{array}{c}0.225 \\
(0.179)\end{array}$ \\
\hline GDP growth (t-2) & $\begin{array}{l}-0.162 \\
(0.139)\end{array}$ & $\begin{array}{l}-0.081 \\
(0.134)\end{array}$ & $\begin{array}{l}-0.219 \\
(0.149)\end{array}$ & $\begin{array}{l}-0.245 \\
(0.151)\end{array}$ & $\begin{array}{l}-0.064 \\
(0.164)\end{array}$ & $\begin{array}{l}-0.160 \\
(0.164)\end{array}$ \\
\hline G7 growth $(\mathrm{t}-1)$ & $\begin{array}{l}0.364^{*} \\
(0.202)\end{array}$ & $\begin{array}{c}0.272 \\
(0.185)\end{array}$ & $\begin{array}{c}0.308 \\
(0.232)\end{array}$ & $\begin{array}{c}0.272 \\
(0.229)\end{array}$ & $\begin{array}{c}0.305 \\
(0.232)\end{array}$ & $\begin{array}{c}0.253 \\
(0.225)\end{array}$ \\
\hline Debt (t-1) & $\begin{array}{l}-0.004 \\
(0.008)\end{array}$ & $\begin{array}{l}-0.007 \\
(0.008)\end{array}$ & $\begin{array}{l}-0.008 \\
(0.011)\end{array}$ & $\begin{array}{l}-0.014 \\
(0.012)\end{array}$ & $\begin{array}{l}-0.006 \\
(0.009)\end{array}$ & $\begin{array}{c}0.003 \\
(0.010)\end{array}$ \\
\hline Expenditure & & $\begin{array}{c}-0.751 * * * \\
(0.262)\end{array}$ & & $\begin{array}{l}-0.367 \\
(0.433)\end{array}$ & & $\begin{array}{c}0.214 \\
(0.378)\end{array}$ \\
\hline Investment & & $\begin{array}{l}-0.255 \\
(0.185)\end{array}$ & & $\begin{array}{c}0.144 \\
(0.225)\end{array}$ & & $\begin{array}{c}-0.427 * \\
(0.244)\end{array}$ \\
\hline Revenues & & $\begin{array}{l}-0.177 \\
(0.285)\end{array}$ & & $\begin{array}{l}-0.189 \\
(0.375)\end{array}$ & & $\begin{array}{l}-0.435 \\
(0.380)\end{array}$ \\
\hline Consolidation & $\begin{array}{c}0.283 \\
(0.187)\end{array}$ & & $\begin{array}{c}0.113 \\
(0.228)\end{array}$ & & $\begin{array}{c}0.291 \\
(0.247)\end{array}$ & \\
\hline Constant & $\begin{array}{c}0.008 \\
(0.009)\end{array}$ & $\begin{array}{c}0.012 \\
(0.009)\end{array}$ & $\begin{array}{c}0.012 \\
(0.012)\end{array}$ & $\begin{array}{c}0.017 \\
(0.013)\end{array}$ & $\begin{array}{c}0.023 * * \\
(0.011)\end{array}$ & $\begin{array}{c}0.014 \\
(0.012)\end{array}$ \\
\hline $\begin{array}{l}\text { Observations } \\
\text { R-squared }\end{array}$ & $\begin{array}{c}72 \\
0.282\end{array}$ & $\begin{array}{c}72 \\
0.428\end{array}$ & $\begin{array}{c}65 \\
0.285\end{array}$ & $\begin{array}{c}65 \\
0.332\end{array}$ & $\begin{array}{c}64 \\
0.117\end{array}$ & $\begin{array}{c}64 \\
0.208\end{array}$ \\
\hline
\end{tabular}

Notes: The table reports point estimates and heteroscedasticity-robust standard errors. $* * *$ Significant at $1 \%, * *$ significant at $5 \%, *$ significant at $10 \%$.

Source: Alesina and Ardagna (2010), OECD Economic Outlook No. 84, own calculations. 
Table 4: Fiscal Adjustments and Growth

\begin{tabular}{|c|c|c|c|c|c|c|}
\hline \multicolumn{7}{|c|}{ Equation estimated: $\Delta Y_{i t}=\alpha_{1} \Delta Y_{i t-1}+\alpha_{2} \Delta Y_{i t-2}+\beta X+\gamma \Delta F A_{i t}+\varepsilon_{i t}$} \\
\hline VARIABLE & $\begin{array}{c}\text { (1) } \\
\text { Replicatio } \\
\text { and Arda }\end{array}$ & $\begin{array}{l}\text { (2) } \\
\text { of Alesina } \\
\text { na }(2010)\end{array}$ & $\begin{array}{c}\text { (3) } \\
\text { Replicatio } \\
\text { and Ard } \\
\text { using the } \\
\mathrm{O}\end{array}$ & $\begin{array}{l}\text { (4) } \\
\text { of Alesina } \\
\text { na }(2010) \\
\text { APB of the } \\
\text { CD }\end{array}$ & \begin{tabular}{|c|}
$(5)$ \\
Replicatio \\
and Ardagn \\
our corre
\end{tabular} & $\begin{array}{l}\text { (6) } \\
\text { f Alesina } \\
\text { 2010) using } \\
\text { d CAPB }\end{array}$ \\
\hline GDP growth (t-1) & $\begin{array}{c}0.296 * * * \\
(0.099)\end{array}$ & $\begin{array}{c}0.288 * * * \\
(0.092)\end{array}$ & $\begin{array}{l}-0.004 \\
(0.137)\end{array}$ & $\begin{array}{l}-0.000 \\
(0.134)\end{array}$ & $\begin{array}{c}0.330 * * * \\
(0.121)\end{array}$ & $\begin{array}{c}0.363 * * * \\
(0.126)\end{array}$ \\
\hline GDP growth $(\mathrm{t}-2)$ & $\begin{array}{l}-0.001 \\
(0.088)\end{array}$ & $\begin{array}{c}0.082 \\
(0.084)\end{array}$ & $\begin{array}{c}0.069 \\
(0.115)\end{array}$ & $\begin{array}{c}0.068 \\
(0.111)\end{array}$ & $\begin{array}{l}-0.046 \\
(0.107)\end{array}$ & $\begin{array}{l}-0.042 \\
(0.109)\end{array}$ \\
\hline G7 growth $(\mathrm{t}-1)$ & $\begin{array}{c}0.116 \\
(0.151)\end{array}$ & $\begin{array}{c}0.038 \\
(0.142)\end{array}$ & $\begin{array}{c}0.210 \\
(0.204)\end{array}$ & $\begin{array}{c}0.001 \\
(0.211)\end{array}$ & $\begin{array}{c}0.191 \\
(0.172)\end{array}$ & $\begin{array}{c}0.132 \\
(0.183)\end{array}$ \\
\hline Debt $(t-1)$ & $\begin{array}{l}-0.011^{*} \\
(0.006)\end{array}$ & $\begin{array}{l}-0.007 \\
(0.006)\end{array}$ & $\begin{array}{l}-0.012^{*} \\
(0.007)\end{array}$ & $\begin{array}{c}-0.015^{* *} \\
(0.007)\end{array}$ & $\begin{array}{l}-0.010^{*} \\
(0.006)\end{array}$ & $\begin{array}{l}-0.010 \\
(0.006)\end{array}$ \\
\hline Expenditure & & $\begin{array}{c}-0.434 * * \\
(0.170)\end{array}$ & & $\begin{array}{l}-0.313 \\
(0.291)\end{array}$ & & $\begin{array}{l}-0.081 \\
(0.207)\end{array}$ \\
\hline Investment & & $\begin{array}{c}0.082 \\
(0.136)\end{array}$ & & $\begin{array}{l}-0.067 \\
(0.172)\end{array}$ & & $\begin{array}{l}-0.064 \\
(0.159)\end{array}$ \\
\hline Revenues & & $\begin{array}{l}-0.216 \\
(0.199)\end{array}$ & & $\begin{array}{l}-0.455^{*} \\
(0.260)\end{array}$ & & $\begin{array}{l}-0.117 \\
(0.232)\end{array}$ \\
\hline Consolidation & $\begin{array}{c}0.044 \\
(0.134)\end{array}$ & & $\begin{array}{l}-0.081 \\
(0.173)\end{array}$ & & $\begin{array}{c}0.052 \\
(0.147)\end{array}$ & \\
\hline Constant & $\begin{array}{c}0.026^{* * * *} \\
(0.007)\end{array}$ & $\begin{array}{c}0.024 * * * \\
(0.007)\end{array}$ & $\begin{array}{c}0.030 * * * \\
(0.007)\end{array}$ & $\begin{array}{c}0.039 * * * \\
(0.008)\end{array}$ & $\begin{array}{c}0.019 * * * \\
(0.007)\end{array}$ & $\begin{array}{c}0.021 * * * \\
(0.008)\end{array}$ \\
\hline $\begin{array}{l}\text { Observations } \\
\text { R-squared }\end{array}$ & $\begin{array}{c}88 \\
0.218\end{array}$ & $\begin{array}{c}88 \\
0.348\end{array}$ & $\begin{array}{c}76 \\
0.073\end{array}$ & $\begin{array}{c}76 \\
0.170\end{array}$ & $\begin{array}{c}80 \\
0.208\end{array}$ & $\begin{array}{c}80 \\
0.219\end{array}$ \\
\hline
\end{tabular}

Notes: The table reports point estimates and heteroscedasticity-robust standard errors. $* * *$ Significant at $1 \%, * *$ significant at $5 \%, *$ significant at $10 \%$.

Source: Alesina and Ardagna (2010), OECD Economic Outlook No. 84, own calculations. 
Table 5: Fiscal Policy and GDP Growth

\begin{tabular}{|c|c|c|c|c|c|c|}
\hline \multicolumn{7}{|c|}{ Equation estimated: $\Delta Y_{i t}=\alpha_{1} \Delta Y_{i t-1}+\alpha_{2} \Delta Y_{i t-2}+\beta X+\gamma \Delta F_{i t}+\mu_{i}+\lambda_{t}+\varepsilon_{i t}$} \\
\hline & \multicolumn{2}{|c|}{$\begin{array}{c}(1) \\
\text { Replication of Alesina } \\
\text { and Ardagna (2010) }\end{array}$} & \multicolumn{2}{|c|}{$\begin{array}{l}\text { (3) } \\
\text { Replication of Alesina } \\
\text { and Ardagna }(2010) \\
\text { using the CAPB of the } \\
\text { OECD }\end{array}$} & \multicolumn{2}{|c|}{$\begin{array}{c}(5) \\
\text { Replication of Alesina } \\
\text { and Ardagna (2010) using } \\
\text { our corrected CAPB }\end{array}$} \\
\hline GDP growth $(\mathrm{t}-1)$ & $\begin{array}{c}0.352 * * * \\
(0.042)\end{array}$ & $\begin{array}{c}0.367 * * * \\
(0.040)\end{array}$ & $\begin{array}{c}0.351 * * * \\
(0.043)\end{array}$ & $\begin{array}{c}0.346 * * * \\
(0.043)\end{array}$ & $\begin{array}{c}0.357 * * * \\
(0.043)\end{array}$ & $\begin{array}{c}0.371 * * * \\
(0.043)\end{array}$ \\
\hline GDP growth $(\mathrm{t}-2)$ & $\begin{array}{l}-0.038 \\
(0.042)\end{array}$ & $\begin{array}{c}0.016 \\
(0.040)\end{array}$ & $\begin{array}{l}-0.045 \\
(0.043)\end{array}$ & $\begin{array}{l}-0.036 \\
(0.043)\end{array}$ & $\begin{array}{l}-0.044 \\
(0.043)\end{array}$ & $\begin{array}{l}-0.040 \\
(0.043)\end{array}$ \\
\hline Debt $(\mathrm{t}-1)$ & $\begin{array}{l}-0.004 \\
(0.004)\end{array}$ & $\begin{array}{c}-0.005 \\
(0.004)\end{array}$ & $\begin{array}{l}-0.003 \\
(0.004)\end{array}$ & $\begin{array}{l}-0.004 \\
(0.004)\end{array}$ & $\begin{array}{l}-0.001 \\
(0.004)\end{array}$ & $\begin{array}{l}-0.002 \\
(0.004)\end{array}$ \\
\hline Expenditure & & $\begin{array}{c}-0.508 * * * \\
(0.061)\end{array}$ & & $\begin{array}{c}-0.169 * * \\
(0.082)\end{array}$ & & $\begin{array}{l}0.123^{*} \\
(0.071)\end{array}$ \\
\hline Investment & & $\begin{array}{l}-0.070 \\
(0.060)\end{array}$ & & $\begin{array}{c}0.057 \\
(0.062)\end{array}$ & & $\begin{array}{l}-0.075 \\
(0.065)\end{array}$ \\
\hline Revenue & & $\begin{array}{c}-0.121 * * \\
(0.061)\end{array}$ & & $\begin{array}{l}-0.099 \\
(0.066)\end{array}$ & & $\begin{array}{c}-0.207 * * * \\
(0.065)\end{array}$ \\
\hline Consolidation & $\begin{array}{c}0.154 * * * \\
(0.039)\end{array}$ & & $\begin{array}{c}0.028 \\
(0.042)\end{array}$ & & $\begin{array}{c}-0.072 * \\
(0.040)\end{array}$ & \\
\hline Observations & 569 & 569 & 566 & 566 & 569 & 569 \\
\hline R-squared & 0.500 & 0.562 & 0.482 & 0.491 & 0.487 & 0.496 \\
\hline Countries & 21 & 21 & 21 & 21 & 21 & 21 \\
\hline R-squared within & 0.500 & 0.562 & 0.482 & 0.491 & 0.487 & 0.496 \\
\hline R-squared between & 0.872 & 0.802 & 0.886 & 0.846 & 0.897 & 0.899 \\
\hline R-squared overall & 0.504 & 0.571 & 0.488 & 0.499 & 0.493 & 0.505 \\
\hline
\end{tabular}

Source: Alesina and Ardagna (2010), OECD Economic Outlook No. 84, own calculations. 
Table 6: Dynamic response of GDP to fiscal consolidation

\begin{tabular}{|c|c|c|c|c|c|c|}
\hline \multicolumn{7}{|c|}{ Equation estimated: $\Delta Y_{i t}=\alpha_{1} \Delta Y_{i t-1}+\alpha_{2} \Delta Y_{i t-2}+\beta X+\gamma_{0} \Delta F A_{i t}+\gamma_{1} \Delta F A_{i t-1}+\gamma_{2} \Delta F A_{i t-2}+\mu_{i}+\lambda_{t}+\varepsilon_{i t}$} \\
\hline \multirow[b]{2}{*}{ GDP growth $(\mathrm{t}-1)$} & \multicolumn{2}{|c|}{$\begin{array}{c}(1) \\
\text { Replication of Alesina } \\
\text { and Ardagna (2010) }\end{array}$} & \multicolumn{2}{|c|}{$\begin{array}{c}\text { (3) } \\
\text { Replication of Alesina } \\
\text { and Ardagna (2010) } \\
\text { using the CAPB of the } \\
\text { OECD }\end{array}$} & \multicolumn{2}{|c|}{$\begin{array}{c}(5) \\
\text { Replication of Alesina } \\
\text { and Ardagna (2010) using } \\
\text { our corrected CAPB }\end{array}$} \\
\hline & $\begin{array}{c}0.319 * * * \\
(0.040)\end{array}$ & $\begin{array}{c}0.325 * * * \\
(0.040)\end{array}$ & $\begin{array}{c}0.391 * * * \\
(0.042)\end{array}$ & $\begin{array}{c}0.394 * * * \\
(0.042)\end{array}$ & $\begin{array}{c}0.302 * * * \\
(0.040)\end{array}$ & $\begin{array}{c}0.309 * * * \\
(0.040)\end{array}$ \\
\hline GDP growth (t-2) & $\begin{array}{l}-0.019 \\
(0.040)\end{array}$ & $\begin{array}{l}-0.014 \\
(0.040)\end{array}$ & $\begin{array}{c}-0.029 \\
(0.041)\end{array}$ & $\begin{array}{l}-0.018 \\
(0.041)\end{array}$ & $\begin{array}{l}-0.022 \\
(0.040)\end{array}$ & $\begin{array}{c}-0.012 \\
(0.040)\end{array}$ \\
\hline Revenues & & $\begin{array}{l}-0.101 \\
(0.133)\end{array}$ & & $\begin{array}{l}-0.140 \\
(0.125)\end{array}$ & & $\begin{array}{c}-0.328 * * * \\
(0.125)\end{array}$ \\
\hline Revenues (t-1) & & $\begin{array}{l}-0.049 \\
(0.134)\end{array}$ & & $\begin{array}{c}-0.314 * * \\
(0.125)\end{array}$ & & $\begin{array}{l}-0.206 \\
(0.127)\end{array}$ \\
\hline Revenues ( $\mathrm{t}-2)$ & & $\begin{array}{c}0.092 \\
(0.133)\end{array}$ & & $\begin{array}{l}-0.014 \\
(0.126)\end{array}$ & & $\begin{array}{c}0.020 \\
(0.128)\end{array}$ \\
\hline Expenditure & & $\begin{array}{c}-0.286^{* *} \\
(0.132)\end{array}$ & & $\begin{array}{c}0.123 \\
(0.193)\end{array}$ & & $\begin{array}{c}0.440 * * * \\
(0.145)\end{array}$ \\
\hline Expenditure (t-1) & & $\begin{array}{l}-0.034 \\
(0.133)\end{array}$ & & $\begin{array}{l}-0.115 \\
(0.193)\end{array}$ & & $\begin{array}{l}-0.191 \\
(0.147)\end{array}$ \\
\hline Expenditure (t-2) & & $\begin{array}{c}0.086 \\
(0.131)\end{array}$ & & $\begin{array}{c}-0.062 \\
(0.188)\end{array}$ & & $\begin{array}{c}0.136 \\
(0.144)\end{array}$ \\
\hline Consolidation & $\begin{array}{c}0.036 \\
(0.067)\end{array}$ & & $\begin{array}{l}-0.078 \\
(0.068)\end{array}$ & & $\begin{array}{c}-0.238 * * * \\
(0.068)\end{array}$ & \\
\hline Consolidation $(\mathrm{t}-1)$ & $\begin{array}{c}0.007 \\
(0.067)\end{array}$ & & $\begin{array}{c}-0.082 \\
(0.068)\end{array}$ & & $\begin{array}{c}-0.023 \\
(0.069)\end{array}$ & \\
\hline Consolidation (t-2) & $\begin{array}{l}-0.025 \\
(0.068)\end{array}$ & & $\begin{array}{c}0.002 \\
(0.069)\end{array}$ & & $\begin{array}{l}-0.020 \\
(0.069)\end{array}$ & \\
\hline Observations & 662 & 662 & 611 & 611 & 662 & 662 \\
\hline R-squared & 0.395 & 0.401 & 0.447 & 0.452 & 0.407 & 0.413 \\
\hline Countries & 21 & 21 & 21 & 21 & 21 & 21 \\
\hline R-squared within & 0.395 & 0.401 & 0.447 & 0.452 & 0.407 & 0.413 \\
\hline $\mathrm{R}$-squared between & 0.921 & 0.928 & 0.954 & 0.941 & 0.850 & 0.745 \\
\hline R-squared overall & 0.407 & 0.417 & 0.468 & 0.475 & 0.410 & 0.415 \\
\hline
\end{tabular}

Notes: The table reports point estimates and heteroscedasticity-robust standard errors. All specifications contain full set of country and time fixed effects (not reported in the table).

*** Significant at $1 \%, * *$ significant at $5 \%,{ }^{*}$ significant at $10 \%$.

Source: Alesina and Ardagna (2010), OECD Economic Outlook No. 84, own calculations. 
Figure 1: Indicators of fiscal policy vs. output gap

Alesina and Ardagna (2010) and OECD method vs. output gap

a) $\mathrm{CAPB}$, Alesina and Ardagna

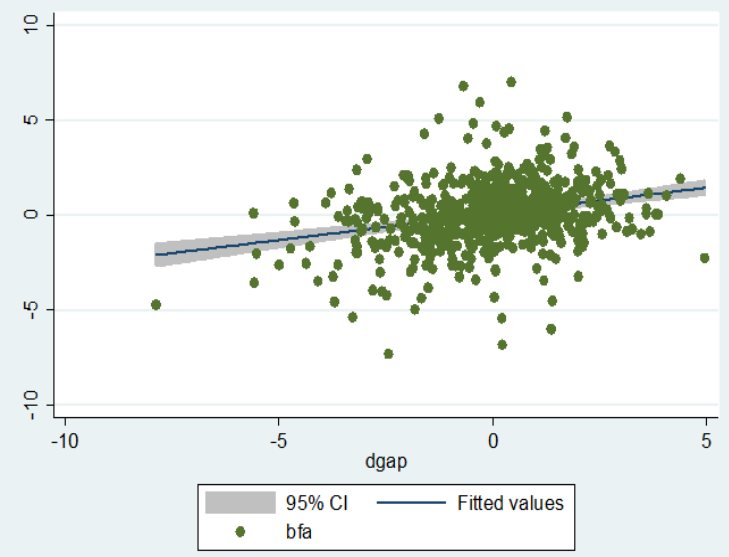

c) Revenues, Alesina and Ardagna

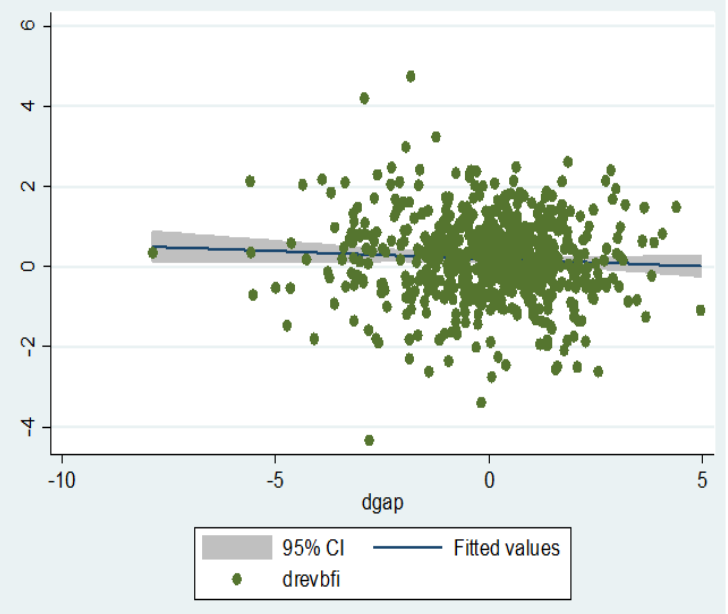

e) Expenditure, Alesina and Ardagna

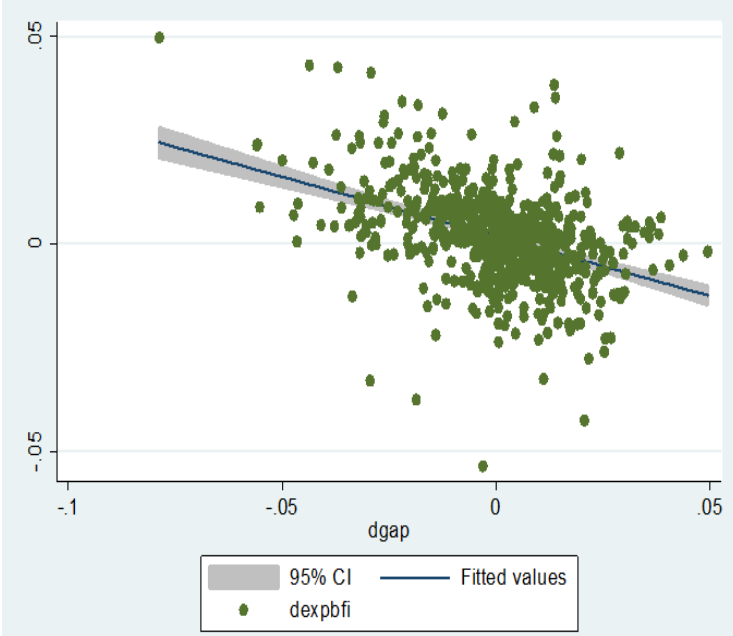

b) CAPB, OECD approach

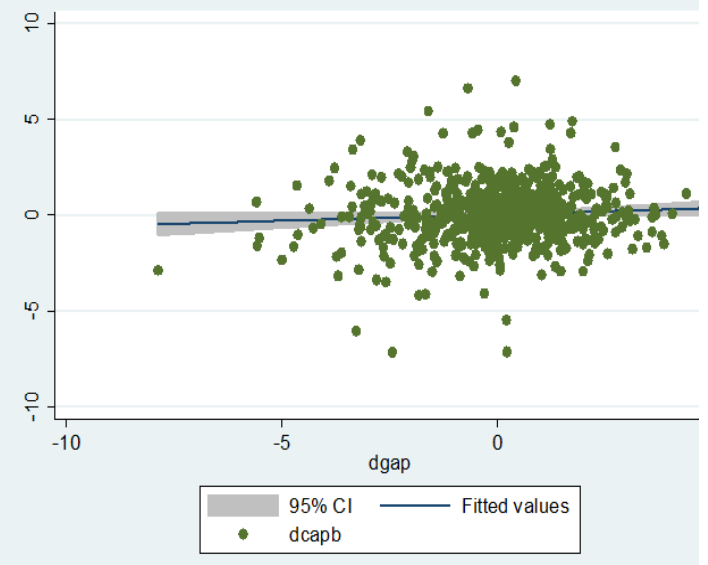

d) Revenues, OECD approach

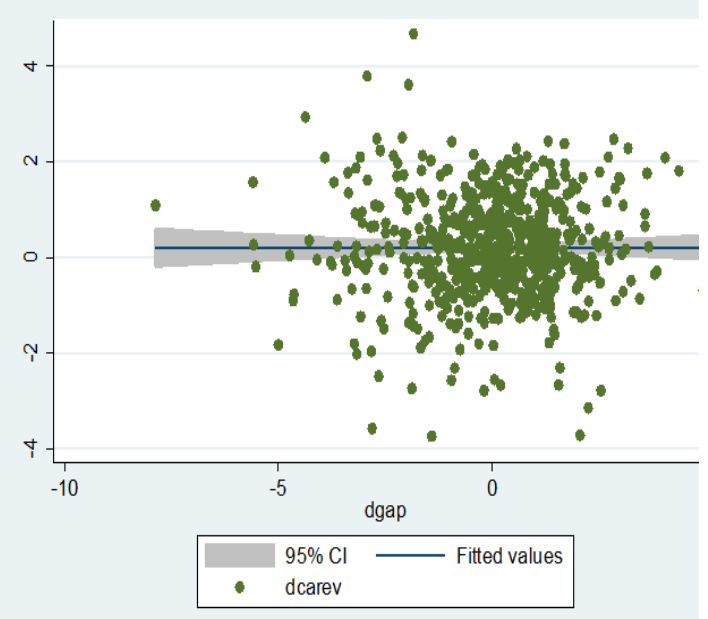

f) Expenditure, OECD approach

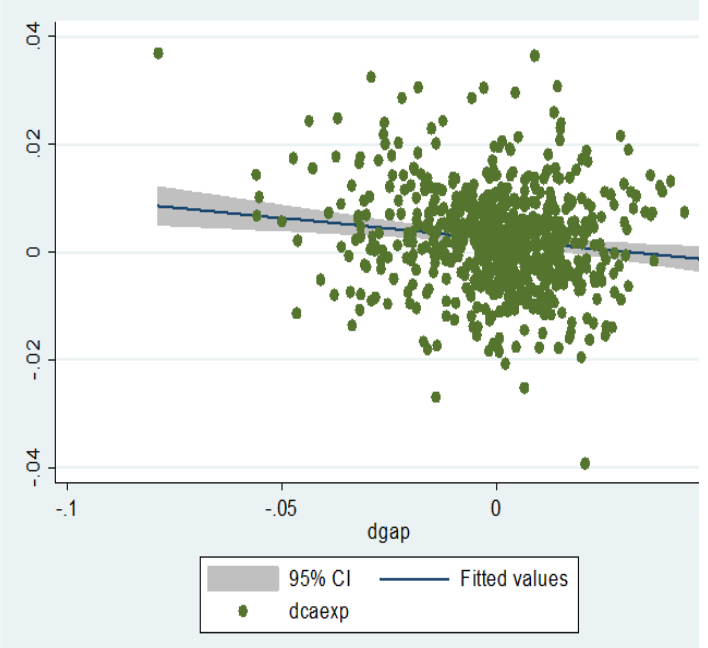

Source: Alesina and Ardagna (2010), OECD Economic Outlook No. 84.

Figure 2: Effects of a 1 percent of GDP fiscal consolidation

Alesina and Ardagna, 2010 vs. OECD method 


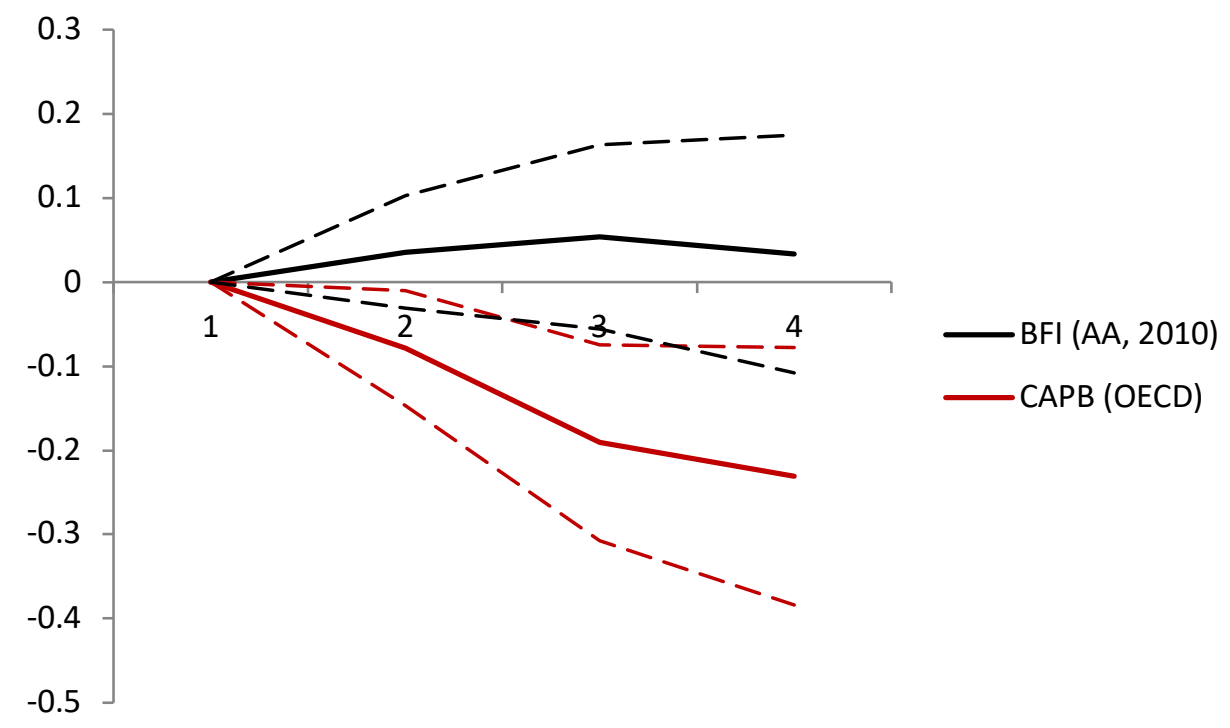

Note: $\mathrm{t}=0$ denotes the year of a 1 percent of GDP fiscal consolidation on GDP. Dotted lines delineate one standard error confidence bands.

\section{Figure 3: Effects of a 1 percent of GDP revenue-based fiscal consolidation}

Alesina and Ardagna, 2010 vs. OECD method

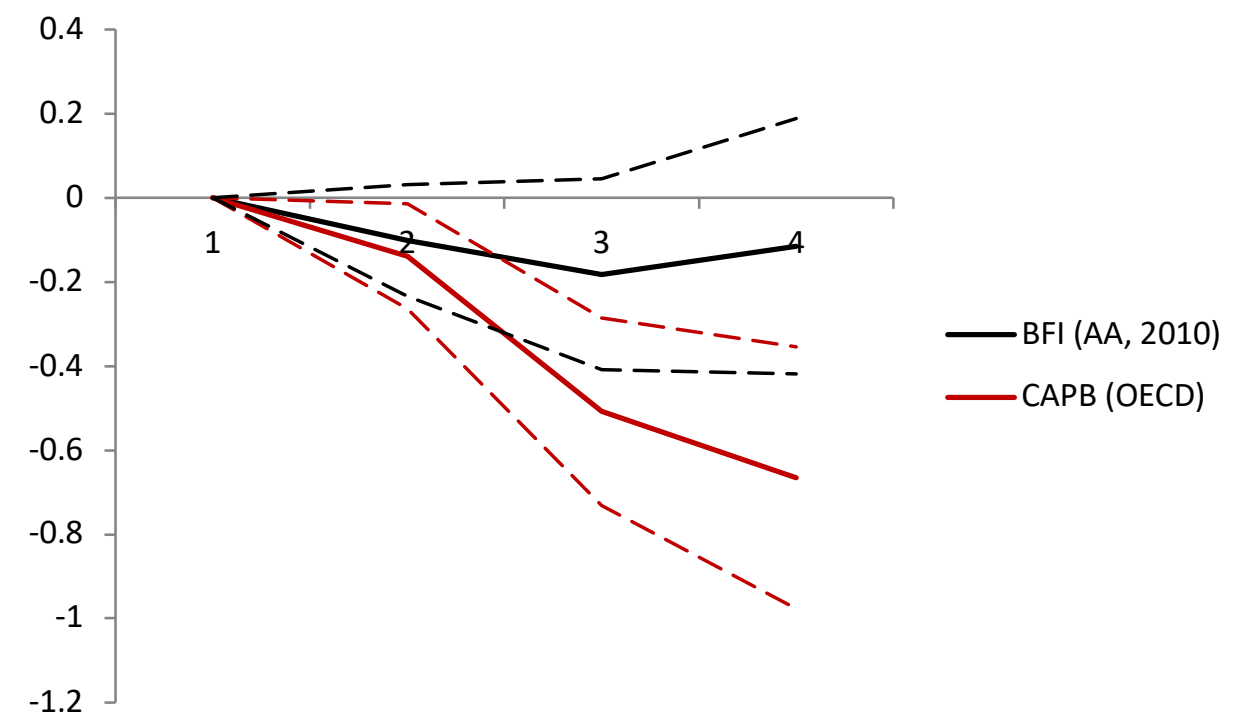

Note: $\mathrm{t}=0$ denotes the year of a 1 percent of GDP revenue-based fiscal consolidation on GDP. Dotted lines delineate one standard error confidence bands.

Figure 4: Effects of a 1 percent of GDP expenditure-based fiscal consolidation 
Alesina and Ardagna, 2010 vs. OECD method

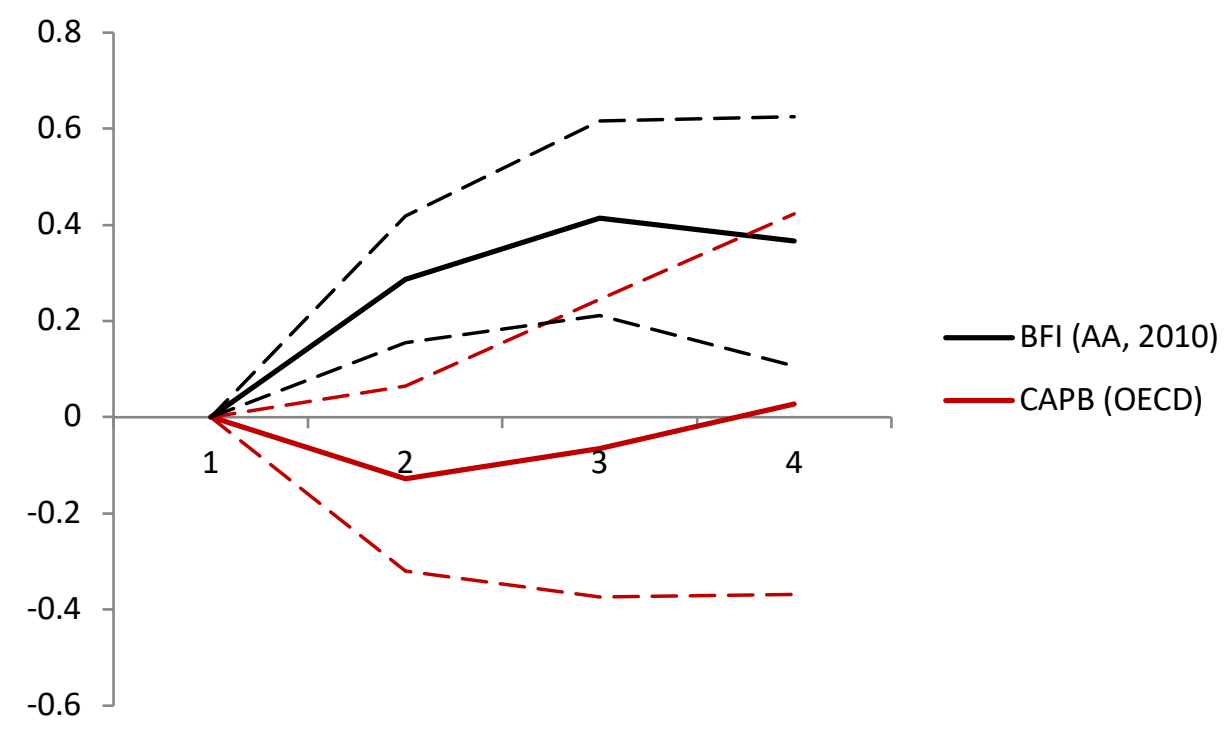

Note: $\mathrm{t}=0$ denotes the year of a 1 percent of GDP expenditure-based fiscal consolidation on GDP. Dotted lines delineate one standard error confidence bands.

Figure 5: Effects of a 1 percent of GDP fiscal consolidation

Alesina and Ardagna, 2010 vs. corrected approach

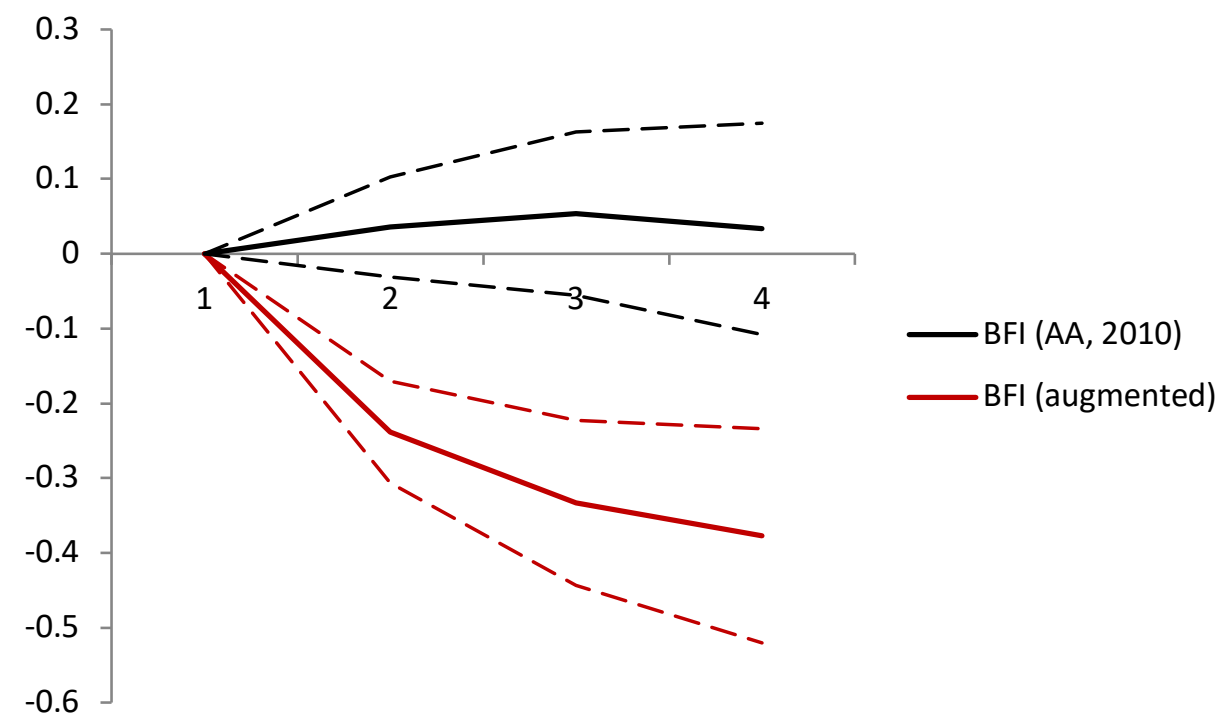

Note: $\mathrm{t}=0$ denotes the year of a 1 percent of GDP fiscal consolidation on GDP. Dotted lines delineate one standard error confidence bands.

Figure 6: Effects of a 1 percent of GDP revenue-based fiscal consolidation 
Alesina and Ardagna, (2010) vs. corrected approach

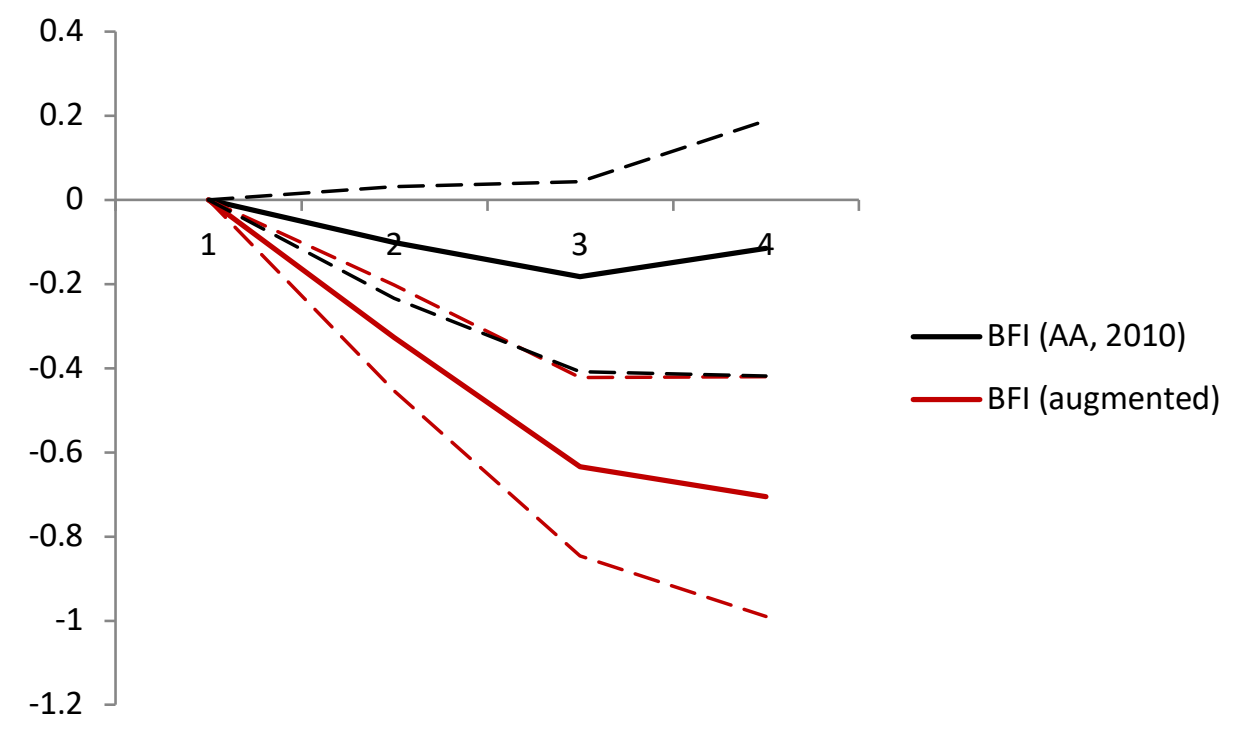

Note: $\mathrm{t}=0$ denotes the year of a 1 percent of GDP revenue-based fiscal consolidation on GDP. Dotted lines delineate one standard error confidence bands.

\section{Figure 7: Effects of a 1 percent of GDP expenditure-based fiscal consolidation}

Alesina and Ardagna (2010) vs. corrected approach

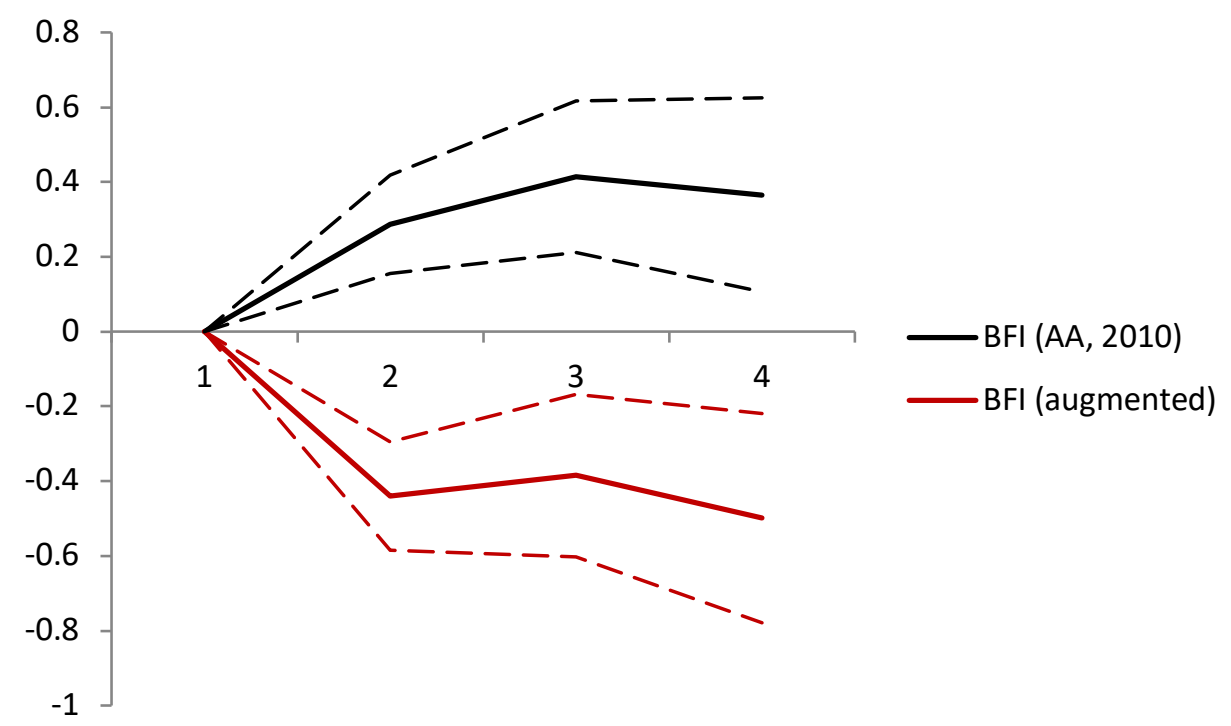

Note: $\mathrm{t}=0$ denotes the year of a 1 percent of GDP expenditure-based fiscal consolidation on GDP. Dotted lines delineate one standard error confidence bands. 


\section{Appendix A: Cyclical Adjustment and Reverse Causality}

Typical cyclical adjustment strategies (as for instance applied in the OECD economic outlook) aim at controlling for automatic feedback from changes in the economic cycle to the budget balance using an estimated budget sensitivity (to the output gap) :

$$
\triangle C A P B_{t}=\Delta P B_{t}-\alpha_{g} \Delta G a p_{t}
$$

Here, $\triangle P B$ indicates the observed change in the primary balance (at the general government level), $\triangle C A P B$ is the cyclically-adjusted primary balance, and Gap represents the output gap (GDP net of potential GDP), where potential GDP is to be measured with a production function or filtering methods, which is a potential source of measurement error. Since a number of authors have been skeptical regarding the reliability of estimations of potential output and the output gap, Blanchard (1990) suggests using the unemployment rate $U R$ as a natural indicator of the economic cycle rather than estimates of the output gap ${ }^{29}$ :

$$
\triangle C A P B_{t}=\Delta P B_{t}-\alpha_{u} \Delta U R_{t}
$$

In a seminal paper, Alesina and Perotti (1995) pioneered the data-based analysis and the so-called "Blanchard method" to adjust the budget balance for cyclical effects with estimations of $\alpha_{u}$. They refer to the estimated change in the fiscal stance as the "Blanchard fiscal indicator" (equation 3). In this article we question whether the cyclically adjustment strategy proposed in Alesina and Perotti (1995) is in line with the assumptions made in the literature on cyclical adjustment.

We follow Fedelino et al. (2009) as a benchmark study on cyclical adjustment and Girouard and André (2005) for a discussion of the OECD cyclical adjustment approach. According to Fedelino et al. (2009), CAPB consists of cyclically-adjusted revenues net

\footnotetext{
${ }^{29}$ According to Blanchard (1990), an estimation of the level of the cyclical position is not necessary, since we are interested in changes in fiscal policy, rather than levels of fiscal positions.
} 
of cyclically-adjusted expenditure, both adjusted with their sensitivity to GDP (with $Y_{t}^{P}$ representing potential GDP) ${ }^{30}$ :

$$
C A P B_{t}=R_{t}\left(\frac{Y_{t}^{P}}{Y_{t}}\right)^{\varepsilon_{R}}-G\left(\frac{Y_{t}^{P}}{Y_{t}}\right)^{\varepsilon_{G}}
$$

The literature on cyclical adjustment proposes the following simplifying assumptions: unit-elastic revenues (responding to the tax base with an elasticity of 1 ), $\varepsilon_{R}=1$, and inelastic government expenditure ( $\varepsilon_{G}=0$ ). If so, equation (3) can be simplified to

$$
C A P B_{t}=R_{t}\left(\frac{Y_{t}^{P}}{Y_{t}}\right)-G_{t}
$$

To adjust the budget balance for cyclical effects, it appears to be reasonable to adjust revenues but not expenditure. Only few expenditure items (unemployment benefits) are affected by the economic cycle. In this line it might be necessary to take into account elastic transfer payments. Following this idea Alesina and Perotti (1995) might assume that social transfers to households, as well as revenues (and only transfers and revenues) respond to cyclical effects. They therefore apply the cyclical adjustment procedure to taxes and transfers, whereas expenditures other than transfers remain unadjusted. According to Alesina and Perotti $(1995)^{31}$, the $\triangle \mathrm{CAPB}$ is

$$
\Delta C A P B_{t}=\Delta R_{t}-\alpha_{R} \Delta U R_{t}-\left(\Delta \operatorname{Tr}_{t}-\alpha_{T r} \Delta U R_{t}\right)-\Delta G_{t}
$$

Rather than computing estimates of potential GDP and output elasticities, it is necessary to compute estimates of the elasticities of transfers and tax revenues to unemployment $\left(\alpha_{R}\right.$ and $\alpha_{T r}$ ). To do so, for each country Alesina and Perotti (1995) regress social transfers as a share of GDP ${ }^{32}$ on two time trends (one for the full period and one for the period after 1975 to control for a potential structural break) ${ }^{33}$ and on the unemployment rate:

$$
\operatorname{Tr}_{t}=a_{0}+a_{1} \cdot \text { trend }_{1}+a_{2} \cdot \text { trend }_{75}+\alpha_{T r} \cdot U R_{t}+e_{t}
$$

\footnotetext{
${ }^{30}$ Note that the CAPB in this illustration is not calculated as a ratio of GDP.

${ }^{31}$ This definition remains relatively similar to the following papers, as e. g. in Alesina and Ardagna $(1998,2010,2013)$.

${ }^{32}$ Note that in Alesina and Perotti (1995) the fiscal variables are expressed as ratios to GDP.

${ }^{33}$ In more recent studies, the second trend is neglected (see Alesina and Ardagna, 2010 and 2013).
} 
Alesina and Perotti (1995) estimate what the transfers would be in period $t$ if unemployment rates were the same as in the previous year:

$$
\operatorname{Tr}_{t}\left(U R_{t-1}\right)=\hat{a}_{0}+\hat{a}_{1} \cdot \text { trend }_{1}+\hat{a}_{2} \cdot \text { trend }_{75}+\hat{\alpha}_{T r} \cdot U R_{t-1}+\hat{e}_{t}
$$

Here, $\hat{a}_{0}, \hat{a}_{1}, \hat{a}_{2}$, and $\hat{\alpha}_{T r}$ represent estimated coefficients (and $\hat{e}$ is the residual) of equation (A6). The difference between unemployment-adjusted transfers $\operatorname{Tr}_{t}\left(U R_{t-1}\right)$ according to equation (A7) and previous' years' transfers $T r_{t-1}$ is regarded as a measure of the change in cyclically-adjusted transfers (equivalent to equation A5):

$$
\Delta C A T r_{t}=\Delta \operatorname{Tr}_{t}-\hat{\alpha_{T r}} \cdot \Delta U R_{t}
$$

The elasticity of transfers with respect to unemployment $\hat{\alpha_{T r}}$ is estimated with equation (A6). The same procedure is applied for revenues to achieve unemployment-adjusted revenues $R_{t}\left(U R_{t-1}\right)$. With estimates of $\operatorname{Tr}_{t}\left(U R_{t-1}\right)$ and $R_{t}\left(U R_{t-1}\right)$, Alesina and Perotti (1995) estimate the primary deficit that would have prevailed in period $t$ if unemployment would be the same rate as in year $t$ - 1 . According to Alesina and Perotti (1995), the $\triangle \mathrm{CAPB}$ (changes in cyclically-adjusted primary balance) is the difference between the unemployment adjusted measure of the primary balance (here, all budget items other than taxes and transfers as a ratio of GDP remain unadjusted) and the previous year's primary balance (equation A5).

\subsection{Scaling and the incomplete cyclical adjustment problem}

The definition of the CAPB in Alesina and Perotti (1995) however is in conflict with standard methods of computing cyclically-adjusted budget balances, for example, the OECD approach (Girouard, André, 2005) or as described in Fedelino et al. (2009). The reason for this is that Alesina and Perotti (1995) do not adjust levels of revenue and expenditure, but revenue and expenditure as a ratio of GDP. To use the variables in databased analyses of fiscal policy it is helpful to scale the variables and express the CAPB as a ratio of GDP (as it is done in the literature). In doing so, following Fedelino et al. (2009), equation (A3) and (A4) will have to be modified: 
(A9) $c a p b_{t}=\frac{C A P B_{t}}{Y_{t}^{p}}=\frac{R_{t}}{Y_{t}}\left(\frac{Y_{t}^{P}}{Y_{t}}\right)^{\varepsilon_{R}-1}-\frac{G_{t}}{Y_{t}}\left(\frac{Y_{t}^{P}}{Y_{t}}\right)^{\varepsilon_{G}-1}=\frac{R_{t}}{Y_{t}}\left(1+g a p_{t}\right)^{-\left(\varepsilon_{R}-1\right)}-\frac{G_{t}}{Y_{t}}\left(1+g a p_{t}\right)^{-\left(\varepsilon_{G}-1\right)}$

Note that gap represents the output gap as a ratio of potential GDP. Assuming unit-elastic revenues $\varepsilon_{R}=1$ and inelastic government expenditure $\varepsilon_{G}=0$ yields

$$
c a p b_{t}=\frac{R_{t}}{Y_{t}}-\frac{G_{t}}{Y_{t}}\left(1+\operatorname{gap}_{t}\right)
$$

The result is different from the CAPB without scaling in equation (A4). Using revenues and expenditures as a ratio of GDP, standard assumptions would suggest adjusting expenditure (as a ratio of GDP), rather than revenue (as a ratio of GDP). ${ }^{34}$

\subsection{Incomplete cyclical adjustment and reverse causality}

Using equation (A9) and (1) to measure the effect of fiscal policy on growth gives

$$
\Delta Y_{t}=\alpha+\beta \Delta\left(\frac{R_{t}}{Y_{t}}\left(1+\operatorname{gap}_{t}\right)^{-\left(-\varepsilon_{R}-1\right)}-\frac{G_{t}}{Y_{t}}\left(1+\operatorname{gap}_{t}\right)^{-\left(\varepsilon_{G}-1\right)}\right)+u_{t}
$$

If $\varepsilon_{R}=1$ and $\varepsilon_{G}=0$

$$
\Delta Y_{t}=\alpha+\beta\left(\Delta\left(\frac{R_{t}}{Y_{t}}\right)-\Delta\left(\frac{G_{t}}{Y_{t}}\left(1+\operatorname{gap}_{t}\right)\right)\right)+u_{t}
$$

Accordingly, government expenditure as a ratio of GDP needs to be corrected for cyclical effects, however, following Alesina and Perotti (1995) and correcting only taxes and transfers as a ratio of GDP, the estimated CAPB (as a ratio of GDP) includes cyclical effects (in the denominator) and consists of (adjusted) revenues as a ratio of GDP, $\left(C A R_{t}\right)$, net of (adjusted) transfers as a ratio of GDP $\left(C A T r_{t}\right)$, net of the ratio of (unadjusted) government expenditure (other than transfers) to GDP $\left(E_{t} / Y_{t}\right)$ :

$$
\Delta Y_{t}=\alpha+\beta \Delta\left(\operatorname{CAR}_{t}-\operatorname{CATr}_{t}-\frac{E_{t}}{Y_{t}}\right)+u_{t}
$$

\footnotetext{
${ }^{34}$ Along these lines Alesina and Perotti (1995) note that using the primary deficit as a share of GDP "is not a bad approximation as long as expenditures and revenues are close to being unit elastic to GDP".
} 
It turns out that, by approximation, the expenditure-to-GDP ratio behaves inversely proportional to the output gap:

$$
\Delta Y_{t}=\alpha+\beta \Delta\left(\operatorname{CAR}_{t}-\operatorname{CATr}_{t}-e_{t}\left(1-\operatorname{Gap}_{t}\right)\right)+u_{t}
$$

Where $e_{t}$ is the structural ratio of expenditure (other than transfers) to potential GDP. It is now obvious that the ratio of government expenditure other than transfers can be influenced by two separate factors, discretionary policy changes that influence the structural expenditure ratio $\left(\Delta e_{t}\right)$ and cyclical effects $\left(\Delta G a p_{t}\right)$. Even without policy changes $\left(\triangle C A R_{t}=0, \Delta C A T r_{t}=0\right.$, and $\left.\Delta e_{t}=0\right)$, and under the simplifying assumption that output growth is a sum of (constant) trend output growth $c$ and changes in the output gap $\left(\Delta Y_{t}=c+\Delta G a p_{t}\right)$, equation (A14) becomes:

$$
c+\Delta \operatorname{Gap}_{t}=\alpha+\beta e_{t} \Delta G a p_{t}+u_{t}
$$

An increase in the output gap ( $\Delta G a p$ ) influences both sides of equation (A15). The conventional method as proposed by Alesina and Perotti (1995) however might interpret an economic upswing (increase in the output gap) as reduction in government spending. 


\section{Appendix B: Cases of Fiscal Adjustment (Replication and Sensitivity of Alesina and Ardagna, 2010)}

Table A1: Fiscal Stimuli (Alesina and Ardagna, 2010)

\begin{tabular}{llllllllll}
\hline Country & \multicolumn{1}{c}{ Fiscal Stimuli (method of Alesina and Perotti, 1995) } \\
\hline Australia & 1990 & 1991 & & & & & & & \\
Austria & 1975 & 2004 & & & & & & & \\
Belgium & 1975 & 1981 & 2005 & & & & & & \\
Canada & 1975 & 1982 & 1991 & 2001 & & & & & \\
Denmark & 1974 & 1975 & 1980 & 1981 & 1982 & & & & \\
Finland & 1978 & 1982 & 1983 & 1987 & 1990 & 1991 & 1992 & 2001 & 2003 \\
France & 1975 & 1981 & 1992 & 1993 & 2002 & & & & \\
Germany & 1995 & 2001 & & & & & & & \\
Greece & 1981 & 1985 & 1989 & 1995 & 2001 & & & & \\
Ireland & 1974 & 1975 & 1978 & 2001 & 2007 & & & & \\
Italy & 1972 & 1975 & 1981 & 2001 & & & & & \\
Japan & 1975 & 1993 & 1998 & 2005 & 2007 & & & & \\
Netherlands & 1975 & 1980 & 1995 & 2001 & 2002 & & & & \\
New Zealand & 1988 & & & & & & & & \\
Norway & 1974 & 1976 & 1977 & 1986 & 1987 & 1991 & 1998 & 2002 & 2007 \\
Portugal & 1978 & 1985 & 1993 & 2005 & & & & & \\
Spain & 1981 & 1982 & 1993 & & & & & & \\
Sweden & 1974 & 1977 & 1978 & 1979 & 1980 & 1991 & 1992 & 2001 & 2002 \\
Switzerland & & & & & & & & & \\
U. Kingdom & 1971 & 1972 & 1973 & 1990 & 1991 & 1992 & 2001 & 2002 & 2003 \\
United States & 2002 & & & & & & & & \\
\hline
\end{tabular}

Source: Alesina and Ardagna (2010), OECD Economic Outlook No. 84, own calculations. 
Table A2: Fiscal Adjustments (Alesina and Ardagna , 2010)

\begin{tabular}{lllllllllll}
\hline Country & \multicolumn{8}{c}{ Fiscal Adjustment (method of Alesina and Perotti, 1995) } \\
\hline Australia & 1987 & 1988 & & & & & & & \\
Austria & 1984 & 1996 & 1997 & 2005 & & & & & \\
Belgium & 1982 & 1984 & 1987 & 2006 & & & & & \\
Canada & 1981 & 1986 & 1987 & 1994 & 1995 & 1996 & 1997 & & \\
Denmark & 1983 & 1984 & 1985 & 1986 & 2005 & & & & \\
Finland & 1973 & 1976 & 1981 & 1984 & 1988 & 1994 & 1996 & 1998 & 2000 & \\
France & 1979 & 1996 & & & & & & & & \\
Germany & 1996 & 2000 & & & & & & & \\
Greece & 1976 & 1986 & 1991 & 1994 & 1996 & 2005 & 2006 & & \\
Ireland & 1976 & 1984 & 1987 & 1988 & 1989 & 2000 & & & \\
Italy & 1976 & 1980 & 1982 & 1990 & 1991 & 1992 & 1997 & 2007 & & \\
Japan & 1984 & 1999 & 2001 & 2006 & & & & & \\
Netherlands & 1972 & 1973 & 1983 & 1988 & 1991 & 1993 & 1996 & & \\
New Zealand & 1987 & 1989 & 1993 & 1994 & 2000 & & & & \\
Norway & 1979 & 1980 & 1983 & 1989 & 1996 & 2000 & 2004 & 2005 & & \\
Portugal & 1982 & 1983 & 1986 & 1988 & 1992 & 1995 & 2002 & 2006 & & \\
Spain & 1986 & 1987 & 1994 & 1996 & & & & & \\
Sweden & 1981 & 1983 & 1984 & 1986 & 1987 & 1994 & 1995 & 1996 & 1997 & 2004 \\
Switzerland & & & & & & & & & & \\
U. Kingdom & 1977 & 1982 & 1988 & 1996 & 1997 & 1998 & 2000 & & \\
United States & & & & & & & & & \\
\hline
\end{tabular}

Source: Alesina and Ardagna (2010), OECD Economic Outlook No. 84, own calculations. 
Table A3: Fiscal Stimuli (CAPB of the OECD)

\begin{tabular}{llllllllll}
\hline Country & \multicolumn{1}{c}{ Fiscal stimuli (OECD measure) } & & & \\
\hline Australia & 1991 & & & & & & & \\
Austria & 1975 & 2004 & & & & & & \\
Belgium & 1972 & 1980 & 1981 & 2005 & & & & \\
Canada & 1975 & 1977 & 2001 & & & & & \\
Denmark & 1975 & 1982 & & & & & & \\
Finland & 1978 & 1979 & 1982 & 1987 & 1990 & 1991 & 1992 & 2001 \\
France & & & & & & & & \\
Germany & 1995 & 2001 & & & & & & \\
Greece & 1981 & 1985 & 1988 & 1989 & 1995 & 2001 & 2003 & 2004 \\
Ireland & 2001 & 2007 & & & & & & & \\
Italy & 1975 & 1981 & 2001 & & & & & \\
Japan & 1972 & 1975 & 1978 & 1993 & 1998 & & & \\
Netherlands & 1975 & 1978 & 1989 & 1995 & 2001 & & & \\
New Zealand & 1988 & & & & & & & & \\
Norway & 1987 & 1990 & 1991 & 1992 & 1996 & 2000 & 2003 & & \\
Portugal & 1985 & 1993 & 2005 & & & & & & \\
Spain & 1990 & & & & & & & \\
Sweden & 1974 & 1977 & 1978 & 1979 & 1980 & 1991 & 1992 & 2001 & 2002 \\
Switzerland & & & & & & & & & \\
U. Kingdom & 1973 & 1978 & 1990 & 1992 & 2002 & 2003 & & & \\
United States & 1975 & 2001 & 2002 & & & & & & \\
\hline
\end{tabular}

Source: OECD Economic Outlook No. 84, own calculations. 
Table A4: Fiscal Adjustments (CAPB of the OECD)

\begin{tabular}{lllllllll}
\hline Country & \multicolumn{7}{c}{ Fiscal adjustment (OECD measure) } \\
\hline Australia & 1998 & & & & & & & \\
Austria & 1984 & 1996 & 1997 & 2001 & 2005 & & & \\
Belgium & 1977 & 1982 & 1984 & 1993 & 2006 & & & \\
Canada & 1981 & 1986 & 1987 & 1995 & 1996 & 1997 & & \\
Denmark & 1983 & 1984 & 1986 & 2004 & 2005 & & & \\
Finland & 1981 & 1984 & 1988 & 1994 & 1996 & 1998 & 2000 & \\
France & 1996 & & & & & & & \\
Germany & 1996 & & & & & & & \\
Greece & 1986 & 1987 & 1991 & 1994 & 1996 & 2005 & 2006 & \\
Ireland & 1983 & 1984 & 1986 & 1987 & 1988 & & & \\
Italy & 1976 & 1982 & 1983 & 1991 & 1992 & 1993 & 1997 & 2007 \\
Japan & 1984 & 1999 & 2006 & & & & & \\
Netherlands & 1972 & 1983 & 1991 & 1993 & 1996 & 2004 & & \\
New Zealand & 1987 & 1989 & 2000 & & & & & \\
Norway & 1983 & 1994 & 1995 & 2007 & & & & \\
Portugal & 1982 & 1983 & 1984 & 1986 & 1992 & 2002 & 2006 & \\
Spain & 1987 & 1992 & 1996 & & & & & \\
Sweden & 1976 & 1981 & 1986 & 1987 & 1994 & 1996 & 1997 & 1998 \\
Switzerland & & & & & & & & \\
U. Kingdom & 1980 & 1982 & 1996 & 1997 & 1998 & & & \\
United States & 1976 & & & & & & & \\
\hline
\end{tabular}

Source: OECD Economic Outlook No. 84, own calculations. 
Table A5: Fiscal Stimuli (CAPB, corrected approach)

\begin{tabular}{|c|c|c|c|c|c|c|c|c|c|c|}
\hline Country & & Fisca & Stimul & (c.a. v & ith the & correct & ed app & ach) & & \\
\hline Australia & & & & & & & & & & \\
\hline Austria & 1975 & 1976 & 2004 & & & & & & & \\
\hline Belgium & 1972 & 1976 & 1980 & 1981 & 2005 & & & & & \\
\hline Canada & 1975 & 2001 & & & & & & & & \\
\hline Denmark & 1975 & 1982 & 1994 & 2006 & & & & & & \\
\hline Finland & 1972 & 1978 & 1979 & 1982 & 1983 & 1987 & 1991 & 2001 & 2003 & \\
\hline France & & & & & & & & & & \\
\hline Germany & 1995 & 2001 & & & & & & & & \\
\hline Greece & 1972 & 1975 & 1981 & 1985 & 1988 & 1989 & 1995 & 2001 & 2003 & 2004 \\
\hline Ireland & 1974 & 1975 & 1978 & 2001 & 2007 & & & & & \\
\hline Italy & 1972 & 1975 & 1981 & 2001 & & & & & & \\
\hline Japan & 1972 & 1975 & 1993 & 1998 & 2005 & 2007 & & & & \\
\hline Netherlands & 1974 & 1975 & 1989 & 1995 & 2001 & & & & & \\
\hline New Zealand & 1988 & & & & & & & & & \\
\hline Norway & 1974 & 1976 & 1977 & 1986 & 1991 & 1997 & 1998 & 2002 & 2007 & \\
\hline Portugal & 1978 & 1985 & 1990 & 2005 & & & & & & \\
\hline Spain & 1993 & & & & & & & & & \\
\hline Sweden & 1974 & 1977 & 1978 & 1979 & 1980 & 1992 & 2001 & 2002 & & \\
\hline Switzerland & & & & & & & & & & \\
\hline U. Kingdom & 1971 & 1972 & 1973 & 1978 & 1992 & 2001 & 2002 & 2003 & & \\
\hline United States & 2002 & & & & & & & & & \\
\hline
\end{tabular}

Source: Alesina and Ardagna (2010), OECD Economic Outlook No. 84, own calculations. 
Table A6: Fiscal Adjustments (CAPB, corrected approach)

\begin{tabular}{llllllllll}
\hline Country & \multicolumn{7}{c}{ Fiscal Adjustment (c.a. with the corrected approach) } \\
\hline Australia & & & & & & & & & \\
Austria & 1984 & 1996 & 1997 & 2005 & & & & & \\
Belgium & 1982 & 1984 & 1987 & 1993 & 2006 & & & & \\
Canada & 1981 & 1986 & 1995 & 1996 & 1997 & & & & \\
Denmark & 1983 & 1984 & 1986 & 2005 & & & & & \\
Finland & 1976 & 1981 & 1984 & 1988 & 1994 & 1996 & 2000 & & \\
France & 1996 & & & & & & & & \\
Germany & 1996 & 2000 & & & & & & & \\
Greece & 1986 & 1987 & 1991 & 1994 & 2005 & 2006 & & & \\
Ireland & 1976 & 1983 & 1984 & 1986 & 1987 & 1988 & 1989 & 2003 & 2004 \\
Italy & 1982 & 1990 & 1991 & 1992 & 1997 & 2007 & & & \\
Japan & 1984 & 1999 & 2001 & 2006 & & & & & \\
Netherlands & 1982 & 1983 & 1988 & 1991 & 1993 & 1996 & 2005 & & \\
New Zealand & 1987 & 1989 & 2000 & & & & & & \\
Norway & 1979 & 1980 & 1983 & 1989 & 1999 & 2000 & 2004 & 2005 & \\
Portugal & 1982 & 1983 & 1984 & 1986 & 1992 & 2002 & 2006 & & \\
Spain & 1983 & 1987 & 1994 & 1996 & & & & & \\
Sweden & 1976 & 1981 & 1986 & 1987 & 1993 & 1994 & 1996 & 1997 & \\
Switzerland & & & & & & & & & \\
U. Kingdom & 1977 & 1980 & 1982 & 1996 & 1997 & 1998 & 2000 & & \\
United States & & & & & & & & & \\
\hline
\end{tabular}

Source: Alesina and Ardagna (2010), OECD Economic Outlook No. 84, own calculations. 


\section{Appendix C. Large Changes in Fiscal Policy (Replication and Sensitivity of Alesina and Ardagna, 2010)}

Alesina and Ardagna (2010) identify episodes of large changes in fiscal policy. According to their definition, an episode of a large fiscal stimulus is an episode when the CAPB (primary deficit, c.a. with the method of Alesina and Perotti, 1995) increases by more than $1.5 \mathrm{pp}$. of GDP in the same year, while an episode of a large fiscal adjustment is an episode when the CAPB (primary deficit, c.a. with the method of Alesina and Perotti, 1995) decreases by more than $1.5 \mathrm{pp}$. of GDP. Following the hypotheses above, it is conceivable that the selection of these episodes is endogenous to economic growth. In particular, the identification as an episode of large fiscal stimulus will be influenced by negative changes in the output gap, while positive changes in the output gap will increase the likelihood of identifying this episode as a large fiscal consolidation.

Table A7 shows the 40 largest economic recessions (negative changes in the output gap) in OECD history (in the dataset of Alesina and Ardagna, 2010). This definition selects several episodes during the oil price crises of 1975 and 1981. To test whether this selection is based on the cyclical adjustment strategy of Alesina and Perotti (1995), the BFI in these episodes is compared with the CAPB (c.a. with OECD method) and it is shown that the CAPB, as estimated with the OECD method, identifies some large recessions as episodes of discretionary fiscal stimulus too, however several of the episodes identified by Alesina and Ardagna (2010) are not large expansionary episodes if the CAPB of the OECD is used. For instance, Canada in 1982 and 1991, as well as Belgium and France in 1975 did not increase the deficit (negative CAPB) by more than 1.5 percentage points, while Alesina and Ardagna (2010) identify these years as episodes of large fiscal expansions (because the CAPB decreases by more than 1.5 percent). This selection points to the two problems highlighted by Perotti (2013), the countercyclical response problem (a), as well as the incomplete cyclical adjustment problem (b). 
First, the countercyclical response problem (a) appears if fiscal policy behaves countercyclically and increases the deficit as a consequence of an economic recession. Table A7 depicts this problem for both indicators whether we rely on the method of Alesina and Perotti (1995) or the CAPB of the OECD. Governments tend to increase deficits in periods of economic slack as a countercyclical policy response, whether the cyclical adjustment strategy is the method of Alesina and Perotti (1995) or the OECD method. This countercyclical response problem is one reason for the critique of the databased approach. However, the CAPB of the OECD selects substantially fewer recessions as episodes of fiscal stimuli, compared to the method of Alesina and Perotti (1995). This, secondly, points to an incomplete cyclical adjustment problem (b) for the literature using the conventional approach and the strategy of Alesina and Perotti (hypothesis 1). This article focuses on the question of how to correct for cyclical effects and whether an incomplete cyclical adjustment influences the results of the fiscal multiplier. We do not elaborate on the countercyclical response problem in more detail, but focus on the incomplete cyclical adjustment problem.

While the CAPB of Alesina and Ardagna (2010) selects 15 of the 40 largest recessions as episodes of fiscal stimulus, the CAPB of the OECD only selects 9. It is thus more likely that the method of Alesina and Perotti interprets an economic downturn as an episode of fiscal expansionism. The imperfect cyclical adjustment problem (b) in the conventional literature thus amplifies the countercyclical response problem (a). We thus do not argue that our results are correct estimations of the fiscal multiplier, but the results are by far more reliable compared to the results in the conventional literature and celebrated during the Eurocrisis.

Table A8 shows a similar picture for the case of economic upturns and fiscal consolidations. While Alesina and Ardagna (2010) select 9 of the 40 largest economic upturns as episodes of fiscal consolidation, the CAPB of the OECD only selects 4 . For instance, United Kingdom in 1988 and New Zealand in 1993 and 1994 shows up as a case of large fiscal consolidation, while the approach of the OECD does not show an increase in the CAPB of more than 1.5 percentage points. It seems that the countercyclical response problem is less distinctive in the case of responding to economic upturns, 
however, the number of cases in which the CAPB of Alesina and Perotti (1995) selects a large episode of economic expansion as period of fiscal consolidation significantly increases (more than doubles), so that the effect of the imperfect cyclical adjustment (in the conventional literature following Alesina and Perotti (1995) should not be underrated. Figure A1 shows the correlation between changes in the economic cycle (output gap) and the CAPB (based on the Blanchard method) in the 40 largest episodes of economic upswings and downturns. It shows a clear negative relationship, suggesting that the CAPB of Alesina and Ardagna tends to be clearly more expansionary in economic recessions, compared to the large episodes of economic upswings (when the CAPB of Alesina seems to be more contractionary). From this picture, it is reasonable to assume a positive correlation between fiscal adjustments and GDP (either through a countercyclical response problem or expansionary austerity). But this relationship is largely influenced by an imperfect cyclical adjustment problem (reverse causality).

Figure A2 depicts the same variables, but now the CAPB is calculated with standard assumptions of the OECD. The clear negative relationship decreases substantially. While the positive relationship is particularly pronounced in the case of economic downturns, it is less significant in the case of economic upswings, pointing to a small remaining countercyclical response problem in times of recessions (probably as a countercyclical response to the oil price crises in 1975 and 1981), while there is little support for a large countercyclical response problem in the case of economic upswings. ${ }^{35}$

In summary, the CAPB of Alesina and Ardagna (2010) appears to be highly correlated with changes in the economic cycle, while the CAPB based on alternative methods is not. This suggests that the CAPB as proposed by Alesina and Perotti (1995) and applied by Alesina and Ardagna (2010) suffers from an incomplete cyclical adjustment problem , as suggested by hypothesis (1). It is shown that the incomplete cyclical adjustment problem increases the likelihood of selecting an economic recession as a fiscal expansion and an economic upswing as an episode of fiscal consolidation. The consequence of this selection bias for the estimated fiscal multiplier is shown in the main part of the paper.

\footnotetext{
${ }^{35}$ The same is true if the CAPB (as computed by Alesina and Ardagna) is contrasted with the corrected 'Blanchard method', rather than the CAPB of the OECD.
} 
Table A7:

40 largest cases of economic downturns

\begin{tabular}{|c|c|c|c|c|c|c|}
\hline Country & Year & $\begin{array}{l}\triangle \mathrm{CAPB} \\
(\mathrm{A} \& \mathrm{P})\end{array}$ & $\begin{array}{l}\text { CAPB } \\
(\mathrm{OECD})\end{array}$ & $\Delta \mathrm{GAP}$ & $\begin{array}{r}\triangle \mathrm{CAPB} \\
(\mathrm{A} \& \mathrm{P})<1.5\end{array}$ & $\triangle \mathrm{CAPB}(\mathrm{OECD})<-1.5$ \\
\hline Finland & 1991 & -4.73 & -2.90 & -7.88 & 1 & 1 \\
\hline Japan & 1974 & 0.09 & 0.69 & -5.60 & & \\
\hline Italy & 1975 & -3.56 & -1.63 & -5.58 & 1 & 1 \\
\hline Canada & 1982 & -2.02 & -1.20 & -5.52 & 1 & \\
\hline Portugal & 1993 & -2.59 & -2.34 & -5.00 & 1 & 1 \\
\hline Finland & 1992 & -1.75 & -1.64 & -4.73 & 1 & 1 \\
\hline Portugal & 1984 & 0.65 & 1.53 & -4.65 & & \\
\hline United States & 1982 & -0.34 & -1.02 & -4.63 & & \\
\hline Belgium & 1975 & -2.53 & 0.34 & -4.37 & 1 & \\
\hline Canada & 1991 & -1.65 & -0.67 & -4.28 & 1 & \\
\hline Spain & 1993 & -3.47 & -0.48 & -4.09 & 1 & \\
\hline United Kingdom & 1980 & 0.66 & 1.79 & -3.91 & & \\
\hline Greece & 1987 & 1.17 & 2.47 & -3.78 & & \\
\hline Austria & 1975 & -3.22 & -2.16 & -3.73 & 1 & 1 \\
\hline Sweden & 1977 & -4.56 & -3.16 & -3.71 & 1 & 1 \\
\hline Australia & 1991 & -2.61 & -1.96 & -3.62 & 1 & 1 \\
\hline United States & 1974 & -0.05 & -0.09 & -3.61 & & \\
\hline Switzerland & 1991 & -0.32 & -0.09 & -3.44 & & \\
\hline Ireland & 1986 & 0.22 & 1.50 & -3.40 & & \\
\hline Austria & 1978 & -0.35 & 0.44 & -3.36 & & \\
\hline Ireland & 1983 & 1.39 & 3.42 & -3.36 & & \\
\hline Japan & 1998 & -5.38 & -6.06 & -3.28 & 1 & 1 \\
\hline United States & 1980 & -0.24 & -0.74 & -3.23 & & \\
\hline United States & 1975 & -1.34 & -2.85 & -3.22 & & 1 \\
\hline France & 1975 & -1.96 & -0.52 & -3.20 & 1 & \\
\hline Portugal & 1983 & 2.39 & 3.91 & -3.19 & & \\
\hline United Kingdom & 1991 & -1.64 & -0.62 & -3.17 & 1 & \\
\hline New Zealand & 1991 & 0.43 & 1.10 & -3.16 & & \\
\hline Australia & 1982 & -0.39 & -0.10 & -3.16 & & \\
\hline Denmark & 1981 & -1.99 & -1.36 & -3.16 & 1 & \\
\hline United Kingdom & 1981 & -0.82 & 0.47 & -3.09 & & \\
\hline Sweden & 1993 & 0.72 & 0.38 & -3.07 & & \\
\hline Ireland & 1991 & -0.73 & 0.06 & -3.04 & & \\
\hline Austria & 1981 & 0.32 & 1.24 & -3.03 & & \\
\hline United States & 1991 & 0.60 & 0.39 & -3.02 & & \\
\hline Australia & 1983 & -0.12 & 0.19 & -2.96 & & \\
\hline Norway & 1989 & 2.97 & -0.74 & -2.94 & & \\
\hline United Kingdom & 1974 & 0.16 & 0.65 & -2.91 & & \\
\hline Belgium & 1993 & 0.67 & 2.10 & -2.91 & & \\
\hline Norway & 1988 & 0.12 & -0.36 & -2.89 & & \\
\hline
\end{tabular}


Table A8:

40 largest cases of economic upswings

\begin{tabular}{|c|c|c|c|c|c|c|}
\hline Country & Year & $\begin{array}{r}\Delta \text { CAPB } \\
(\mathrm{A} \& \mathrm{P})\end{array}$ & $\begin{array}{l}\triangle \mathrm{CAPB} \\
(\mathrm{OECD}) \\
\end{array}$ & $\Delta \mathrm{GAP}$ & $\begin{array}{c}\Delta \mathrm{CAPB} \\
(\mathrm{A} \& \mathrm{P})>1.5\end{array}$ & $\begin{array}{c}\Delta \mathrm{CAPB} \\
(\mathrm{OECD})>-1.5\end{array}$ \\
\hline United Kingdom & 1973 & -2.26 & -3.75 & 4.95 & & \\
\hline Portugal & 1988 & 1.92 & 1.12 & 4.39 & 1 & \\
\hline Denmark & 1976 & 1.01 & 0.07 & 4.06 & & \\
\hline Ireland & 1990 & 0.06 & -1.49 & 3.87 & & \\
\hline Greece & 1978 & 0.04 & -1.09 & 3.81 & & \\
\hline United States & 1984 & -0.85 & 0.02 & 3.67 & & \\
\hline Norway & 1985 & 1.15 & 0.37 & 3.63 & & \\
\hline Portugal & 1989 & 0.08 & -0.88 & 3.59 & & \\
\hline Japan & 1973 & 0.36 & -0.12 & 3.59 & & \\
\hline Finland & 1979 & -1.00 & -1.69 & 3.47 & & \\
\hline Portugal & 1987 & -0.73 & -1.09 & 3.25 & & \\
\hline Australia & 1984 & -0.13 & -0.22 & 3.19 & & \\
\hline Japan & 1972 & -0.86 & -1.77 & 3.13 & & \\
\hline Finland & 1997 & 1.07 & 1.14 & 3.08 & & \\
\hline Belgium & 1973 & 1.09 & -0.32 & 3.07 & & \\
\hline Finland & 1989 & 1.12 & 0.21 & 3.04 & & \\
\hline Italy & 1976 & 2.43 & 2.15 & 3.01 & 1 & 1 \\
\hline Canada & 1984 & 0.77 & -0.07 & 2.99 & & \\
\hline Spain & 1987 & 2.88 & 1.71 & 2.98 & 1 & 1 \\
\hline Ireland & 1997 & 1.10 & 0.15 & 2.90 & & \\
\hline Denmark & 1994 & -0.62 & -0.60 & 2.89 & & \\
\hline Finland & 1988 & 3.34 & 2.37 & 2.85 & 1 & 1 \\
\hline Japan & 1988 & -0.15 & -0.07 & 2.76 & & \\
\hline United Kingdom & 1988 & 1.66 & 0.63 & 2.75 & 1 & \\
\hline Belgium & 1976 & -0.02 & -0.92 & 2.74 & & \\
\hline Denmark & 1986 & 3.64 & 3.55 & 2.73 & 1 & 1 \\
\hline New Zealand & 1994 & 2.07 & 1.40 & 2.69 & 1 & \\
\hline Austria & 1979 & 0.29 & -0.23 & 2.66 & & \\
\hline Greece & 1988 & -1.01 & -2.02 & 2.56 & & \\
\hline United States & 1973 & 0.55 & 0.40 & 2.55 & & \\
\hline New Zealand & 1993 & 1.89 & 1.05 & 2.53 & 1 & \\
\hline Netherlands & 1976 & 0.21 & 0.83 & 2.53 & & \\
\hline Canada & 1973 & 1.06 & 0.47 & 2.50 & & \\
\hline Belgium & 1988 & 0.45 & -0.81 & 2.45 & & \\
\hline United States & 1978 & -0.08 & 0.17 & 2.43 & & \\
\hline Italy & 1979 & -0.03 & -0.61 & 2.41 & & \\
\hline Sweden & 1984 & 2.30 & 1.20 & 2.41 & 1 & \\
\hline Ireland & 1999 & -0.35 & -1.27 & 2.34 & & \\
\hline Canada & 1999 & 0.79 & 0.33 & 2.29 & & \\
\hline Canada & 1988 & 0.72 & 0.26 & 2.28 & & \\
\hline
\end{tabular}


Figure A1: $\triangle$ CAPB (Alesina and Ardagna, 2010) vs. $\Delta$ Gap in large episodes of upand downswing

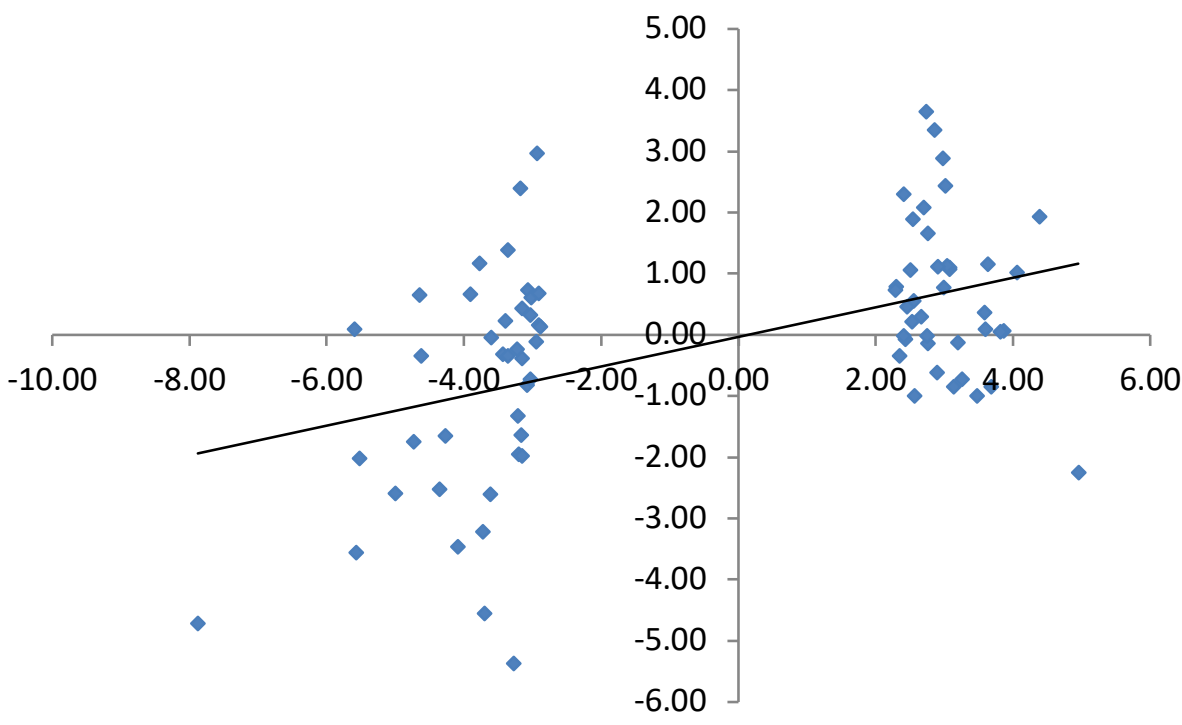

Source: Alesina and Ardagna (2010), OECD Economic Outlook, No. 84, own calculations.

Figure A2: $\triangle \mathrm{CAPB}$ (OECD) vs. $\triangle$ Gap in large episodes of up- and downswing

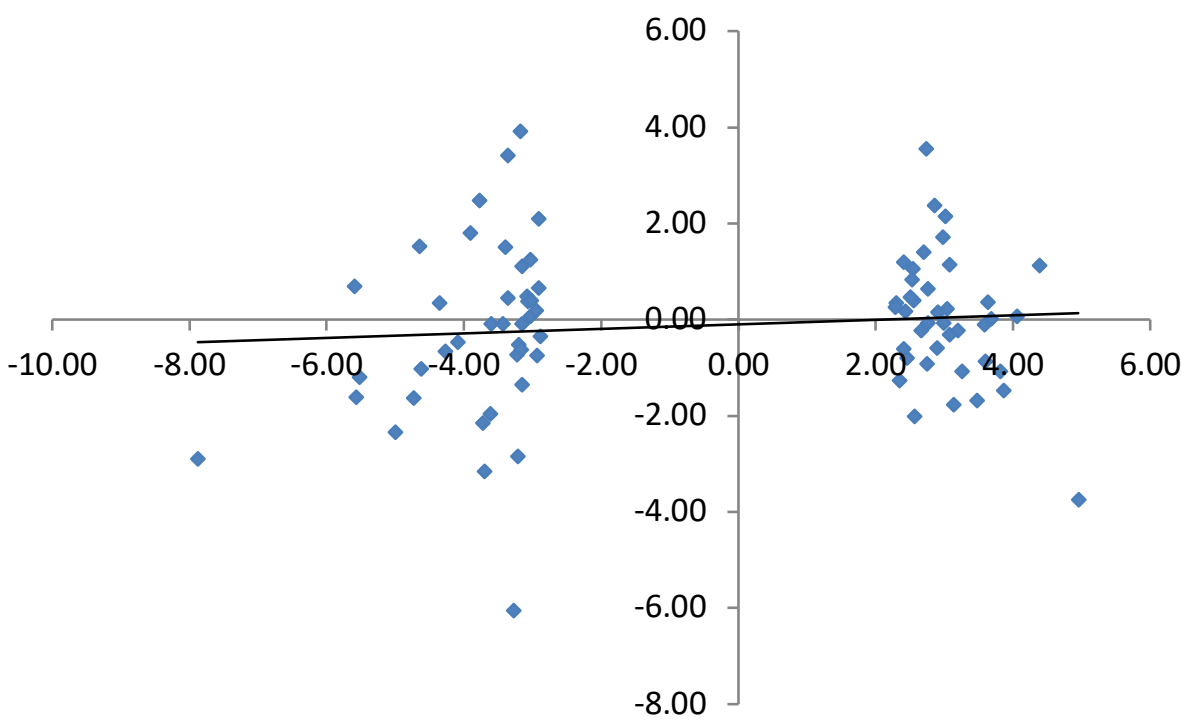

Source: OECD Economic Outlook, No. 84, own calculations. 